\title{
Dietary chalcones with chemopreventive and chemotherapeutic potential
}

\author{
Barbora Orlikova $\cdot$ Deniz Tasdemir • \\ Frantisek Golais · Mario Dicato $\cdot$ Marc Diederich
}

Received: 23 July 2010/Accepted: 6 January 2011/Published online: 4 February 2011

(C) Springer-Verlag 2011

\begin{abstract}
Chalcones are absorbed in the daily diet and appear to be promising cancer chemopreventive agents. Chalcones represent an important group of the polyphenolic family, which includes a large number of naturally occurring molecules. This family possesses an interesting spectrum of biological activities, including antioxidative, antibacterial, anti-inflammatory, anticancer, cytotoxic, and immunosuppressive potential. Compounds of this family have been shown to interfere with each step of carcinogenesis, including initiation, promotion and progression. Moreover, numerous compounds from the family of dietary chalcones appear to show activity against cancer cells, suggesting that these molecules or their derivatives may be considered as potential anticancer drugs. This review will focus primarily on prominent members of the chalcone family with an 1,3-diphenyl-2-propenon core structure. Specifically, the inhibitory effects of these compounds on the different steps of carcinogenesis that reveal interesting chemopreventive and chemotherapeutic potential will be discussed.
\end{abstract}

Keywords Diet . Chalcone derivatives .

Chemoprevention · Chemotherapy

B. Orlikova · M. Dicato · M. Diederich $(\bowtie)$

Laboratoire de Biologie Moléculaire et Cellulaire du Cancer,

Fondation de Recherche Cancer et Sang, Hôpital Kirchberg,

9 Rue Edward Steichen, 2540 Luxembourg, Luxembourg

e-mail: marc.diederich@lbmcc.lu

D. Tasdemir

Department of Pharmaceutical and Biological Chemistry,

The School of Pharmacy, University of London,

29-39 Brunswick Square, London WC1N 1AX, UK

F. Golais

Department of Microbiology and Virology, Faculty of Sciences,

Comenius University, Bratislava, Slovakia

\section{Introduction}

Polyphenols represent one of the most prevalent classes of compounds found in our daily diet [171]. Over the last ten years, increasing attention has been dedicated to chalcones because of their interesting biological activities. Indeed, chalcones constitute an important group of natural compounds that are especially abundant in fruits (e.g., citruses, apples), vegetables (e.g., tomatoes, shallots, bean sprouts, potatoes) and various plants and spices (e.g., licorice),many of which have been used for centuries in traditional herbal medicine [29]. Chemically, chalcones are openchain flavonoids bearing two aromatic rings linked by a three-carbon enone moiety (Fig. 1). The majority of the content of chalcones in citrus fruits and various plants is mediated through the formation of 4,2', $4^{\prime}, 6^{\prime}$-tetrahydroxychalcone (also known as naringenin chalcone (1)) by chalcone synthase (Fig. 2) [77]. Naringenin chalcone (1) also plays an essential role in the flavonoid biosynthetic pathway and contributes significantly to the total amount of plant flavonoids [35]. Although chalcones occur naturally, they could be available in larger amounts through an efficient and simple synthesis. Briefly, synthesis through basecatalyzed Claisen-Schmidt condensation of an aromatic aldehyde and an appropriate ketone in a polar solvent (methanol or ethanol) renders them a readily available nutrition component/supplement in either natural or synthesized form [147] (Fig. 3).

The present paper is primarily concerned with chalcone derivatives found in edible plants, fruits, and vegetables and with their positive effects in cancer chemoprevention and carcinogenesis. Cancer chemoprevention can target each step of carcinogenesis with natural or synthetic substances [160]. Because of unsatisfactory cancer treatment options and adverse side effects caused by currently used 


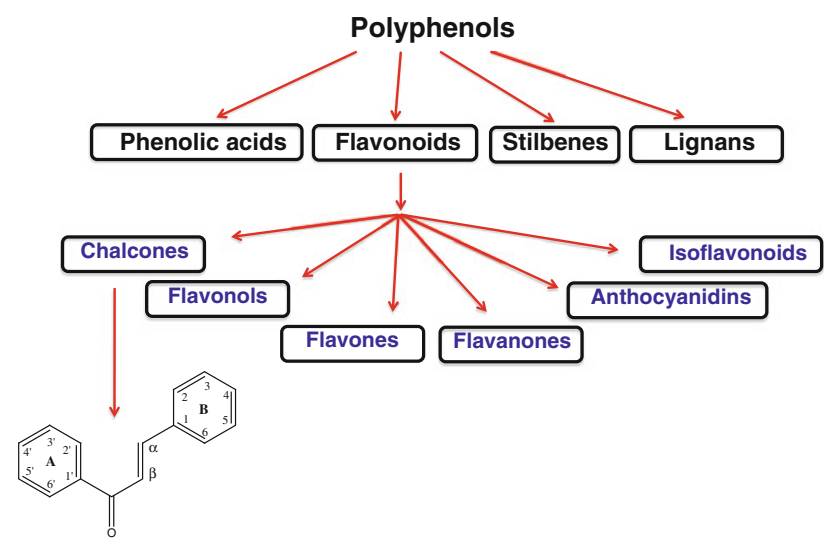

Fig. 1 Schematic representation of main polyphenol family members. Polyphenols are subdivided into 4 main classes-phenolic acids, flavonoids, stilbenes, and lignans - according to the number of phenol rings they include and the structural elements that bind these rings together [114]. Flavonoids can be further divided into various subclasses of which chalcones, flavonols, flavones, flavanones, anthocyanidins, and isoflavonoids are the most common. The core 1,3-diphenyl-2-propenon chalcone structure is shown

chemotherapeutic compounds, great emphasis has been put on the use of non-toxic dietary substances and botanical products, either alone or in a co-treatment.

Various chalcones completely inhibit different steps of carcinogenesis from the very early stages, including tumor initiation, through promotion, progression, angiogenesis, and invasion, to the very late stages leading to metastasis. They are also strongly implicated in the negative regulation of cell cycle progression and favor cell death mechanisms, predominantly apoptosis, in transformed cells. Moderation of these processes is generally associated with the involvement of chalcones in an elaborate network of inflammatory cell-signaling pathways that largely contribute to tumor promotion.

This review will focus on members of the chalcone class with the 1,3-diphenyl-2-propenon core structure and the inhibitory effect of these compounds on the different steps of carcinogenesis that highlight their interesting chemopreventive and chemotherapeutic potential.

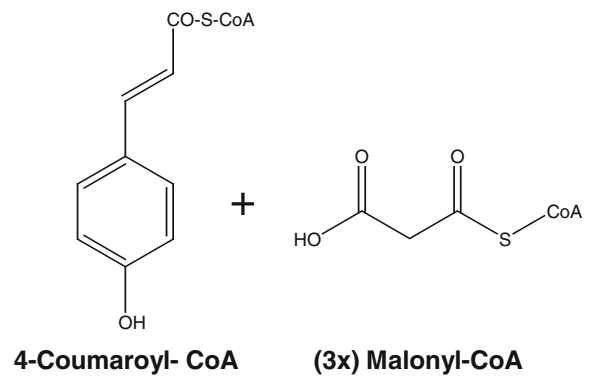

Fig. 2 Biosynthesis of naringenin chalcone in plants and citruses. The condensation of three molecules of malonyl-CoA and one molecule of 4-coumaroyl-CoA is catalyzed by chalcone synthetase

\section{Inflammation cell-signaling pathways targeted by chalcones}

The tight interplay between chronic inflammation and cancer was first established and carefully documented by Virchow in 1863 when he observed leukocytes in neoplastic tissues. Since then, many scientists have provided evidence underlining the strong dependency between these two processes. Natural compounds, including chalcones, have been shown to interact with, abrogate, and abolish inflammatory signaling (see Fig. 4). Moreover, a single compound can target multiple signaling events and contribute to inhibition of the synthesis of inflammatory mediators.

Nuclear factor (NF)- $\kappa \mathrm{B}$ is a mediator of inflammatory diseases and cancer and has been shown to induce resistance to various chemotherapeutic agents. This transcription factor is implicated in immunity, anti-apoptosis, proliferation, and activation of more than 550 target genes involved in tumor promotion, angiogenesis, and metastasis. The canonical NF$\kappa \mathrm{B}$ pathway is characterized by a cascade leading to activation of the functional heterodimer p50/p65. After stimulation by tumor necrosis factor (TNF) $\alpha$, activation of the I $\kappa$ kinase (IKK) complex leads to phosphorylation of the inhibitory subunit $\mathrm{I} \kappa \mathrm{B} \alpha$ followed by subsequent proteasomal degradation. As a result, NF- $\kappa$ B p50/p65 translocates to the nucleus and transcription is activated.

Besides NF- $\kappa \mathrm{B}$ signaling, other pathways are strongly linked to inflammation processes, including extracellular signal-regulated kinase (ERK), c-Jun N-terminal kinases (JNK), and p38 signal transduction pathways. The ERK1/ 2-mediated signaling pathway is activated by growth factors, cytokines, carcinogens, or viral proteins. Initially, this pathway was thought to be limited exclusively to cell growth and proliferation, but there is growing evidence indicating its involvement in several inflammatory processes [136]. The family of JNK enzymes is implicated in cell proliferation, survival, and apoptosis through the activation of stress and inflammation. Inhibition of JNKmediated AP-1 activation is a promising approach for inhibition of the inducible expression of inflammatory 
<smiles>O=C(/C=C/c1ccc(O)cc1)c1c(O)cc(O)cc1O</smiles><smiles>O=C(/C=C/c1ccc(O)cc1)c1ccc(O)cc1O</smiles><smiles>CC1(C)C=Cc2cc(/C=C/C(=O)c3ccc4c(c3O)CCC(C)(C)O4)ccc2O1</smiles><smiles>C[C@H]1[C@H](C[C@@H]2[C@@H](O)C(CO)O[C@@](C)(O)[C@@H]2Oc2ccc(/C=C/C(=O)c3ccc(O)cc3O)cc2)OCC12COC2</smiles><smiles>COc1cc(O)c(CC=C(C)C)c(O)c1C(=O)/C=C/c1ccc(O)cc1</smiles>

3 1,2-dihydroparatocarpin A

4 isoliquiritin apioside

5 xanthohumol<smiles>CC(C)=CCc1cc(C(=O)/C=C/c2ccc(O)c(O)c2)c(O)cc1O</smiles><smiles>O=C(CCc1ccc(O)cc1)c1c(O)cc(O)cc1O</smiles><smiles>O=C(CCc1ccc(O)cc1)c1c(O)cc(O)cc1O</smiles>

6 broussochalcone $\mathrm{A}$<smiles>COc1c(C)c(O)c(C(=O)CCc2ccccc2)c(O)c1C</smiles>

8 phloridzin

9 myrigalone B<smiles>O=C(/C=C/c1ccccc1)c1ccccc1</smiles>

10 chalcone<smiles>CC(C)C(O)Cc1c(O)cc(O)c(C(=O)/C=C/c2ccc(O)cc2)c1O</smiles>

13 xanthohumol D<smiles>O=C(/C=C/c1ccc(O)c(O)c1)c1ccc(O)cc1O</smiles>

16 butein<smiles>O=C(/C=C/c1ccccc1O)c1ccccc1</smiles>

11 2-hydroxychalcone<smiles>CC=CCc1c(O)cc(O)c(C(=O)CCc2ccc(O)cc2)c1O</smiles>

14 dihydroxanthohumol<smiles>O=C(/C=C/c1ccc(O)cc1)c1ccccc1</smiles>

17 4-hydroxychalcone<smiles>COc1cc2c(c(O)c1C(=O)/C=C/c1ccc(O)cc1)CC(O)C(C)(C)O2</smiles>

12 xanthohumol B<smiles>CC(C)=CCc1c(O)ccc(C(=O)/C=C/c2ccc(O)cc2)c1O</smiles>

15 isobavachalcone<smiles>C=CC(C)(C)Cc1cc(/C=C/C(=O)c2ccc(O)cc2)c(O)cc1O</smiles>

18 licochalcone $A$

Fig. 3 Chemical structures of naturally occurring chalcone derivatives

genes in cancer and other pathologies [115]. The p38 mitogenactivated protein kinase (MAPK) pathway is critical for the synthesis and activity of multiple pro-inflammatory cytokines (TNF- $\alpha$, interleukin (IL)-1, IL-6, IL-8).
Finally, the crosstalk of these pathways with NF- $\kappa$ B cell signaling contributes to induction of key inflammatory enzymes such as cyclooxygenase (COX)- 2 and inducible nitric oxide synthase (iNOS) [27]. 


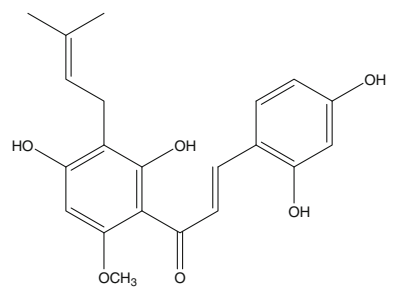<smiles>O=C(/C=C/c1ccc(O)c(O)c1O)c1ccc(O)cc1</smiles>

20 licochalcone B<smiles>CC(C)=CCc1cc(C(=O)/C=C/c2ccc(O)c(O)c2O)ccc1O</smiles>

19 7,9,2',4'-tetrahydroxy-8-isopentenyl-5-methoxychalcone

21 licochalcone D<smiles>COc1cc(O)cc(O)c1C(=O)/C=C/c1ccccc1</smiles><smiles>COc1ccc(/C=C/C(=O)c2c(O)cc(OC)cc2OC)cc1</smiles>

HO<smiles>OCC1OC2CCC1O2</smiles>

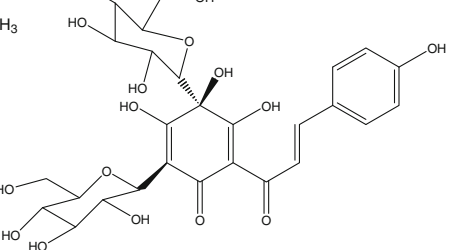

22 cardamonin

23 flavokawain A

24 hydroxysafflor yellow $\mathrm{A}$<smiles>O=C(/C=C/c1ccc(O)c(O[C@@H]2O[C@H](CO)[C@@H](O)[C@H](O)[C@H]2O)c1)c1ccc(O[C@@H]2O[C@H](CO)[C@@H](O)[C@H](O)[C@H]2O)cc1O</smiles>

25 isobutrin<smiles>CC(C)=CCc1c(O)cc(Br)c(CC=Cc2ccc(C)cc2)c1C</smiles>

26 desmethylxanthohumol<smiles>COc1cc(O)c(C(=O)CCc2ccc(O)cc2)c(O)c1</smiles>

27 asebogenin<smiles>COc1cc(O)ccc1C(=O)/C=C/c1ccc(O)cc1</smiles>

28 isoliquiritigenin $2^{\prime}$-methyl ether<smiles>O=C(/C=C/c1ccccc1)c1ccc(O)cc1O</smiles>

29 2',4'-dihydroxychalcone<smiles>COc1ccc(/C=C/C(=O)c2ccc(O)cc2O)cc1</smiles>

30 isoliquiritin<smiles>COc1c(C)c(O)c(C)c(O)c1C(=O)/C=C/c1ccccc1</smiles>

$31 \mathrm{ON}-\mathrm{III}$<smiles>COc1ccc(C(=O)/C=C/c2ccccc2)c(O)c1</smiles>

32 2'-hydroxy-4'-methoxychalcone (c)

33 xanthoangelol<smiles>COc1ccc(C(=O)/C=C/c2ccc(O)cc2)c(O)c1CC=C(C)C</smiles>

34 4-hydroxyderricin<smiles>O=c1cc(-c2ccccc2)oc2cc3oc4ccccc4c3c(O)c12</smiles>

35 uvaretin<smiles>COc1c(C(=O)/C=C/c2ccccc2)c(O)cc(O)c1-c1ccccc1O</smiles>

36 isouvaretin

Fig. 3 continued

It has been reported that chalcone (10) provided two distinct cytoprotective mechanisms, depending on the duration of pre-treatment. Initially, chalcone (10) abrogated time and dose dependently the activation of signal transducer and activator of transcription (STAT)3 and NF- $\kappa \mathrm{B}$ in IL-6 and lipopolysaccharide (LPS)- 
<smiles>COc1c(C(=O)/C=C/c2ccccc2)c(O)c(-c2ccccc2O)c(O)c1-c1ccccc1O</smiles>

37 diuvaretin<smiles>C=C(C)C(C)c1cc(/C=C/C(=O)c2ccc(O)cc2)c(OC)cc1O</smiles>

38 licochalcone E<smiles>CC(C)=CCCC1(C)C=Cc2cc(C(=O)/C=C/c3ccc(O)cc3)c(O)cc2O1</smiles>

39 isolespeol<smiles>COc1cc(O)c(C(=O)/C=C/c2ccccc2)c(OC)c1</smiles>

40 flavokawain B

Fig. 3 continued

stimulated endothelial cells via depletion of intracellular glutathione (GSH) levels. Prolonged chalcone treatment (after $6 \mathrm{~h}$ and $12 \mathrm{~h}$ ), however, rescued the intracellular GSH level, indicating the activation of thiol-related genes. This second cytoprotective mechanism involved the chalcone-mediated accumulation of NFE2-related factor (Nrf)2 in the nucleus, which led to elevated protein levels of thioredoxin reductase and heme oxygenase (HO)-1 [108].

Heme oxygenase-1 plays an important role in inflammatory responses. Its activity catalyzes heme degradation, leading to the production of carbon monoxide (CO) and biliverdin, which is further reduced to bilirubin. Heme oxygenase-1 activity results in cytoprotection against oxidative injury and cellular stresses [5]. As reported, the prenylated chalcone $7,9,2^{\prime}, 4^{\prime}$-tetrahydroxy-8-isopentenyl5-methoxychalcone (19) from Sophora flavescens successfully inhibited expression of interferon (INF)- $\gamma$ and tumor necrosis factor alpha (TNF- $\alpha$ )-induced chemokines (TARC/CCL17, MDC/CCL22, CTACK/CCL27) via induction of HO-1 [22].

Licochalcone A (18) strongly inhibited NF- $\kappa$ B nuclear localization along with the subsequent DNA binding and transcriptional activities induced by TNF- $\alpha$. Mechanistic studies with licochalcone A (18) uncovered the underlying mechanism; the repression was not due to impairment of receptor-interacting protein (RIP) or IKK- $\beta$ recruitment to tumor necrosis factor receptor (TNFR)1 but rather arose from inhibition of IKK activation and subsequent $\mathrm{I} \kappa \mathrm{B}$ degradation. The authors suggested that cysteine 179 of the IKK complex is essential for licochalcone A-induced IKK inhibition [39]. Interestingly, Furusawa et al. [41] demonstrated that if NF- $\kappa \mathrm{B}$ was induced by LPS, the effect of licochalcone A (18) appeared further downstream at the level of p65. Licochalcone A (18) strongly inhibited phosphorylation of p65 at serine 276 leading to abrogation of its interaction with p300 and subsequent reduction in $\mathrm{NF}-\kappa \mathrm{B}$ transactivation. Later on, a similar mechanism leading to inhibition of LPS-induced NF- $\kappa$ B activation was also confirmed for licochalcone B (20) and licochalcone D (21) together with reduced LPS-induced production of nitric oxide (NO), TNF- $\alpha$, and monocyte chemoattractant protein (MCP)-1 [40].

A similar mechanism was observed for cardamonin (22), a natural product from Artemisia absinthium. NF- $\kappa$ B activation and related iNOS production in LPS-stimulated cells were inhibited by a direct effect on the capacity of the transcription factor to bind DNA [50]. Interestingly, Israf et al. [60] reported inhibition of COX-2 and iNOS expression by cardamonin (22) via dose-dependent suppression of $\mathrm{I} \kappa \mathrm{B} \alpha$ phosphorylation and degradation in LPS-induced RAW 264.7 macrophages, clearly describing a cell-type-specific effect of this compound. A similar effect on the NF- $\kappa$ B pathway was reported for broussochalcone A (6) by Cheng et al. [19].

Additionally, inhibition of NF- $\kappa$ B activity by downregulation of the IKK complex has been reported for flavokavain A (23), which is isolated from Piper methysticum. p38-regulated/activated kinase (PRAK) and MAPK-activated protein kinase (MAPKAP-K)-3 were also suppressed, as demonstrated by a group from Scotland and Luxembourg [36]. 


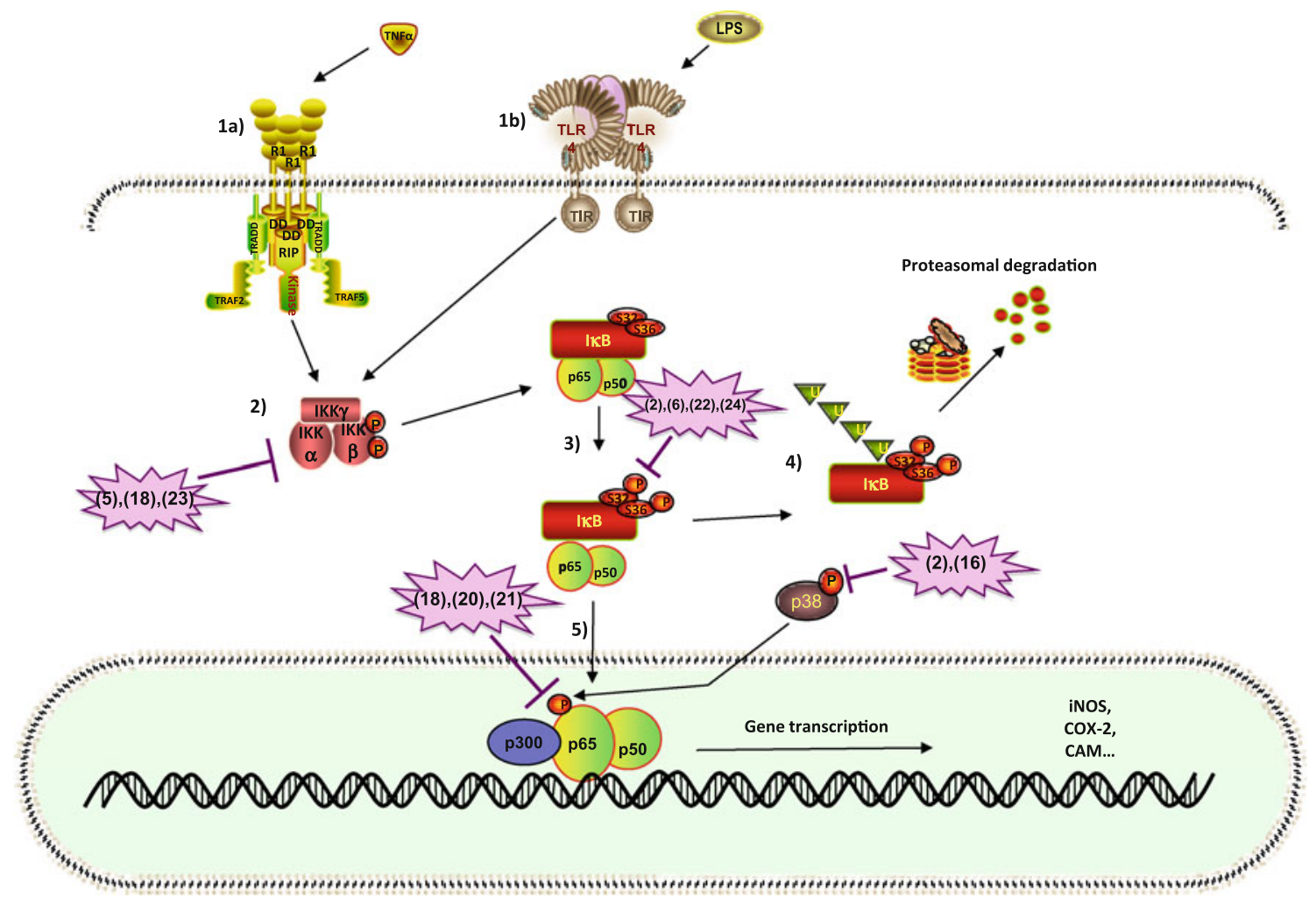

Fig. 4 Involvement of naturally occurring chalcone derivatives in the NF- $\kappa \mathrm{B}$ inflammation pathway. 1a $\mathrm{TNF} \alpha$ and/or 1b LPS ligands interact with corresponding receptors, recruiting several signaling proteins to form a primary signaling complex. 2 Transmission of signal resulting in IKK activation. 3 IKK subsequently phosphorylates serines 32 and 36 of the $\mathrm{I} \kappa \mathrm{B}$ inhibitor, 4 which in turn creates binding sites for ubiquitination and shifts $\mathrm{I} \kappa \mathrm{B}$ to proteasomal degradation. $5 \mathrm{NF}-\kappa \mathrm{B}$ subunits are released from the inhibitor complex and translocated to the nucleus where they bind DNA and activate transcription of several genes. Chalcone derivatives block the NF- $\kappa \mathrm{B}$

Modification of IKK and p65 cysteine residues after xanthohumol (5) treatment of leukemia cells was described by Harikumar et al. [48] Xanthohumol (5) downregulated both constitutive and inducible NF- $\kappa \mathrm{B}$ activities. Furthermore, direct inhibition of IKK activation was related to xanthohumol-mediated alteration of the cysteine 179 residue, whereas direct binding inhibition of p65 to DNA could be linked to modification of a p65 cysteine residue. Cho et al. [21] demonstrated that in INF- $\gamma$-stimulated RAW 264.7 macrophages, xanthohumol (5) inhibited binding activity of STAT- $1 \alpha$ and interferon regulatory factor (IRF)- 1 .

Hydroxy safflor yellow A (24), the main active monomer of Carthamus tinctorius, significantly inhibited phosphorylation of $\mathrm{I} \kappa \mathrm{B} \alpha$ and subsequent $\mathrm{p} 65$ transactivation by preventing its translocation to the nucleus. The transcriptional level of pro-inflammatory cytokines TNF- $\alpha$, IL- $1 \alpha$, and IL- 6 was reduced, while mRNA expression of antiinflammatory cytokine IL-10 was potentiated [18]. pathway at different steps: inhibition of IKK activity (chalcones $\mathbf{5}, \mathbf{1 8}$, 23), suppression of $\mathrm{I} \kappa \mathrm{B} \alpha$ phosphorylation (chalcones $2, \mathbf{6}, \mathbf{2 2}, \mathbf{2 4}$ ), direct inhibition of p65 binding to DNA (chalcones 18, 20, 21) or reduction in $\mathrm{p} 38$ phosphorylation (chalcones 2, 16). Arrows represent induction/activation and blunt-ended lines represent repression/inactivation. Abbreviations: $T N F \propto$ tumor necrosis factor alpha, $L P S$ lipopolysaccharide, $I \kappa B$ inhibitor of kappa B, IKK I $\kappa \mathrm{B}$ kinase, $N F-\kappa B$ nuclear factor kappa B. This figure was generated with ScienceSlides software

Naringenin chalcone (1), abundant in tomato skin, inhibited in a dose-dependent manner the production of pro-inflammatory mediators such as TNF- $\alpha$, MCP-1, and NO in LPS-stimulated macrophages [53].

Kim et al. [70] reported that the anti-inflammatory properties of isoliquiritigenin (2) are mediated by downregulation of iNOS, COX-2, TNF- $\alpha$, and IL- 6 . These proteins were downregulated by inhibition of $\mathrm{NF}-\kappa \mathrm{B}$ via suppression of IKK, ERK1/2 and reduction in p38 phosphorylation. Inhibition of NF- $\kappa$ B activation by blocking the phosphorylation and subsequent degradation of $\mathrm{I} \kappa \mathrm{B} \alpha$ has also been reported independently by Kumar et al. and Kwon et al. [81, 84]. Isoliquiritigenin (2) potentiated HO-1 expression through the ERK1/2 pathway in RAW 267.4 cells, thus effectively inhibiting macrophage-derived inflammation [93]. In prostate cancer cells, isoliquiritigenin (2) inhibited cancer cell invasion and migration by abrogating JNK/AP-1 signaling [83]. 




Fig. 5 Involvement of naturally occurring chalcone derivatives in regulation of the cell cycle. Chalcone derivatives may induce ATM (chalcone 2), which in turn phosphorylates p53, thus decreasing p53/ MDM2 interaction. However, ATM augmentation subsequently leads to phosphorylation of Chk1 and Chk2 and reduces the level of Cdc25c resulting in G2/M arrest. By activating inhibitors of Cdks (p21 and p27), chalcone derivatives may participate in cell cycle arrest in either

Butein (16) has been shown to act as an anti-inflammatory agent useful in the treatment of intestinal inflammation. In TNF- $\alpha$-stimulated HT-29 colon adenocarcinoma cells, butein (16) inhibited p38 phosphorylation and osteopontin-mediated $\mathrm{I} \kappa \mathrm{B} \alpha$ phosphorylation [92]. Moreover, Pandey et al. [138] investigated the mechanism by which butein (16) attenuates $\mathrm{I} \kappa \mathrm{B} \alpha$ phosphorylation. They reported that IKK is inactivated directly via the cysteine 179 residue. A co-isolated constituent from Butea monospera extract, isobutrin (25), also displayed potent inhibitory activity toward IKK complex activity [149].

Similar effects on various inflammatory pathways and HO-1 activation have been published for a variety of synthetic chalcone derivatives with structures optimized for improved functionality [5, 94, 96, 140, 141].

\section{Chalcones as inhibitors of the cell cycles}

As mentioned previously, the antiproliferative activity of chalcone derivatives is tightly linked with cell cycle arrest and initiation of the cellular apoptotic machinery. Cyclins and cyclin-dependent kinases (Cdks) are two key regulatory factors and are crucial components of cell cycle progression. Alterations to the expression or post-
G1 or G2/M phase (chalcones 2, 10, 18, 23). Arrows represent induction/activation and blunt-ended lines represent repression/inactivation. Abbreviations: $C d k$ cyclin-dependent kinase, ATM ataxia telangiectasia mutated, Chk checkpoint homolog serine/threonineprotein kinase, $C d c 25 c$ cell division cycle 25 homolog $\mathrm{C}$. This figure was generated with ScienceSlides software

transcriptional modifications of these compounds lead to deregulation of cell cycle functions. Involvement of diverse chalcone derivatives in these processes has been described (see Fig. 5).

Chalcone (10) alone showed potential to interact with cell cycle progression. The simultaneous enhancement of p21 and p27 expression and reduction of cyclin B1, cyclin A, and Cdc2 levels leads to G2/M phase arrest in both human MCF-7 and MDA-MB-231 breast cancer cell lines as well as in human T24 and HT-1376 bladder cancer cell lines [57, 158].

Isoliquiritigenin (2) was shown to reduce cyclin D1, cyclin E, and Cdk4 levels, which together with increased p27 levels contributed to downregulation of the cyclin D1-Cdk4 complex and induced early G1 arrest in human DU145 and rat MLL prostate cancer cells. In addition, phosphorylation of cell division cycle (Cdc)2 was enhanced concurrent with reduction of $\mathrm{Cdc} 25 \mathrm{c}$ levels, leading to inactivation of Cdc2-cyclin B1 complexes and subsequent late G2/M phase arrest [97]. Similarly, perturbation of the cell cycle at the G2/M phase by induction of universal inhibitors of Cdks, such as p21 (CIP1/WAF1) and p27, was observed in leukemia CCRF-CEM cells [195], human cervical cancer HeLa cells [139], uterine leiomyoma cells [68], human hepatoma Hep G2 cells [54], human 
lung cancer A549 cells [59], and human prostate cancer LNCaP cells [65].

Licochalcone A (18) led to $\mathrm{G} 2 / \mathrm{M}$ arrest by similar mechanisms via induction of p21 and p27, attenuation of Cdks 2, 4, and 6, and downregulation of cyclin D1 in androgen-independent PC-3 prostate cancer cells [38, 188].

Flavokavain A (23), the major component of the traditional kava tea consumed predominately by men in Fiji, Vanautu and Western Samoa, produced cell cycle arrest by different mechanisms in cells expressing wild-type p53 versus cells expressing mutated p53. In p53 wild-type RT4 cells, flavokavain A (23) mediated arrest in G1 phase by accumulation of Cdk2 kinase inhibitors p21 and p27. In p53 mutated cell lines, however, flavokavain A (23) prevented the G2/M transition via persistent activation of Cdk1 kinase activity and increased levels of cyclin B1, which counteracted the decreased level of Cdc25C. The Cdk1-inhibitory kinases Myt1 and Wee1 were suppressed, allowing Cdk1 to remain dephosphorylated [167].

A promising strategy leading to disruption of aberrant cell cycle progression of defective cells is attenuation or abrogation of MDM2/p53 complex formation. The oncoprotein MDM2 inhibits the tumor suppressor protein $\mathrm{p} 53$, which is considered a genome integrity checkpoint. Inactivated p53 has been shown to be expressed in many human tumors. Stoll et al. [162] reported that chalcone derivatives might antagonize the interaction between MDM2 and p53 by binding to a subsite of the p53-binding cleft of human MDM2, thereby releasing p53 from the complex and restoring its transcriptional activity. The stability of p53 can be further enhanced by activation of ataxia telangiectasia mutated (ATM), which phosphorylates p53 at serine 15 , thus decreasing p53/MDM2 interaction. Studies performed by Hsu et al. [58] in human cervical carcinoma $\mathrm{HeLa}$ cells revealed that isoliquiritigenin-mediated cell cycle blockade in G2/M phase is associated with extended activation of ATM accompanied by phosphorylation of Chk2 and Cdc25c and subsequent p53 phosphorylation. The p53-dependent inhibition of the cell cycle in G1 phase has been described [55]. Similar patterns have been reported for butein (16), where the growth of hepatoma cancer cells was inhibited via ATM augmentation, followed by Chk1 and Chk2 phosphorylation and Cdc25c level reduction leading to G2/M phase arrest [120].

Synthetic chalcones were shown to disrupt the p53MDM2 binding, resulting in elevated p53 activity that explained previously observed anticancer properties [14].

The ability of chalcones to interact with tubulin, leading to alterations in the microtubule network, indicates another mechanism that results in cell cycle blockade. In several cases, the cytotoxicity-mediated inhibition of cell growth by chalcones correlates with their capability to bind to tubulin and thereby abrogate microtubule polymerization
[86]. Although there are few known inhibitors of tubulin assembly among naturally occurring chalcones, a large library of chalcone analogues was synthesized. Many showed convincing antimitotic properties as microtubuledepolymerizing agents with $\mathrm{IC}_{50}$ values of sub- $\mu \mathrm{M}$ and low $\mu \mathrm{M}$ concentrations (see Table 1) $[10,31,69,87]$.

\section{Chalcones as inducers of cell death mechanisms}

The induction of apoptosis is a hallmark of cancer treatment. A large spectrum of chalcone derivatives with proapoptotic properties have been found in various edible or medicinal plants. Induction of apoptosis in gastric cancer cells has been reported for $2^{\prime}, 4^{\prime}$-dihydroxychalcone (29) isolated from Herba oxytropis [110] and for uvaretin (35), isouvaretin (36), and diuvaretin (37) from Uvaria acuminata in leukemia cells [125]. Similarly, $2^{\prime}, 4^{\prime}$-dihydroxy-6'methoxy- $3^{\prime}, 5^{\prime}$-dimethylchalcone (ON-III) (31) extracted from buds of traditional Chinese medicinal herb Cleistocalyx operculatus, which are used for a preparation of herbal tea in Vietnam, triggered apoptosis in breast and leukemia cancer cells [101, 181]. Licochalcone E (38) isolated from Glycyrrhiza inflata induced apoptosis in endothelial cells [17].

An important apoptotic cell death mechanism is activated via the TNF superfamily members, particularly tumor necrosis factor-related apoptosis-inducing ligand (TRAIL). TRAIL selectively induces programmed cell death via interaction with death receptors TRAIL-R1 (DR4) or/and TRAIL-R2 (DR5) in various cancer cells without a harmful effect on normal tissue. However, reduced expression of these receptors or elevated expression of antiapoptotic proteins leads to TRAIL resistance $[169,189]$. The involvement of specific chalcones in apoptotic cell death is summarized in Fig. 6.

Szliszka et al. [166] showed that chalcone (10) and four of its natural analogues, licochalcone A (18), isobavachalcone (15), xanthohumol (5), and butein (16), strongly enhanced the apoptosis-inducing potential of TRAIL and thus sensitized TRAIL-resistant LNCaP prostate cancer cells.

Cardamomin (22), a chalcone isolated from Catimbium speciosum, which is used as herbal tea or in essential oils, enhanced TRAIL-induced apoptosis in TRAIL-resistant cells. The underlying mechanism includes increased expression of death receptor (DR) 4 and DR5 and reduced $\mathrm{Bcl}-\mathrm{xL}$ levels following cardamomin treatment of human colorectal adenocarcinoma DLD1 cells [134]. Butein (16) alone has been shown to induce apoptosis in human leukemia HL-60 cells via positive modulation of caspase-3 activity associated with downregulation of $\mathrm{Bcl}-2$ expression and upregulation of Bax expression [72]. Subtoxic 
Table 1 Semi-synthetic and synthetic chalcone derivatives as antiproliferative agents

\begin{tabular}{|c|c|c|c|}
\hline Chalcone derivative & Parent natural product (if available) & Targeted cellular processes & References \\
\hline 15 dihydroartemisinin derivatives & Artemisinin (Artemisia аппиа) & $\begin{array}{l}\text { Cell viability } \\
\text { Cell proliferation apoptosis }\end{array}$ & [179] \\
\hline 21 derivatives polyoxygenated on the A ring & Tangeretin (Citrus) & Cell proliferation & {$[145]$} \\
\hline Boronic acid CA-4 analogues:cis- 6 , trans- 6 & $\begin{array}{l}\text { Combretastatin A4 (Combretum } \\
\text { caffrum) }\end{array}$ & $\begin{array}{l}\text { Cell proliferation } \\
\text { Inhibition of tubulin assembly }\end{array}$ & [79] \\
\hline 4 analogues & $\begin{array}{l}\text { Combretastatin A4 (Combretum } \\
\text { caffrum) }\end{array}$ & $\begin{array}{l}\text { Cell proliferation } \\
\text { Inhibition of tubulin assembly } \\
\text { angiogenesis }\end{array}$ & {$[78]$} \\
\hline 97 combretastatin-like chalcones & $\begin{array}{l}\text { Combretastatin A4 (Combretum } \\
\text { caffrum) }\end{array}$ & $\begin{array}{l}\text { Cell viability } \\
\text { Cell cycle } \\
\text { Inhibition of tubulin assembly }\end{array}$ & {$[31]$} \\
\hline 65 derivatives with basis functionalities & & Cell proliferation & {$[107]$} \\
\hline 19 methoxylated derivatives & & $\begin{array}{l}\text { Cell proliferation } \\
\text { Cell viability inflammation }\end{array}$ & [8] \\
\hline $12 \beta$-chlorovinyl derivatives & & Cell proliferation inflammation & [7] \\
\hline 17 piperidinylchalcones derivatives & & $\begin{array}{l}\text { Cell proliferation } \\
\text { Cell cycle }\end{array}$ & [106] \\
\hline $\begin{array}{l}\text { RVC-588 } \\
\text { (4,4'-dihydroxychalcone) }\end{array}$ & & $\begin{array}{l}\text { Cell viability } \\
\text { Cell proliferation } \\
\text { Cell death }\end{array}$ & [156] \\
\hline $2^{\prime}, 4^{\prime}, 6^{\prime}$-tris(methoxymethoxy) chalcone & & Cell proliferation & {$[95]$} \\
\hline $\begin{array}{l}\text { 4'-(p-toluenesulfonylamido)-4- } \\
\text { hydroxychalcone }\end{array}$ & & Cell proliferation & [91] \\
\hline JAI-51 & & $\begin{array}{l}\text { Cell proliferation } \\
\text { Cell cycle } \\
\text { Inhibition of tubulin assembly }\end{array}$ & {$[10]$} \\
\hline MDL-27048 & & $\begin{array}{l}\text { Cell proliferation } \\
\text { Cell cycle } \\
\text { Inhibition of tubulin assembly }\end{array}$ & {$[69]$} \\
\hline 644 chalcone derivatives & & $\begin{array}{l}\text { Cell proliferation } \\
\text { Cell cycle } \\
\text { Inhibition of tubulin assembly }\end{array}$ & {$[87]$} \\
\hline
\end{tabular}

concentrations of butein (16) in combination with TRAIL increased expression of DR5 and boosted caspase-3 activity, allowing apoptosis in TRAIL-resistant U937 cells [71]. Similarly, subtoxic combinations of isoliquiritigenin (2) and TRAIL rapidly induced apoptosis in colon cancer HT29 cells by influencing the interaction between TRAIL and its receptor [186]. In prostate and gastric cancer cells and human cervical carcinoma HeLa cells, isoliquiritigenin (2) disrupted the mitochondrial membrane potential, resulting in mitochondrial apoptotic pathway activation [58, 64, 111].

A novel approach to the induction of apoptosis is the use of 'mitocans', therapeutic and preventive drugs that preferentially target mitochondria and possess anticancer activity [146]. Xanthohumol (5) corresponds well to this definition; it is able to inhibit complexes I-III of the respiratory chain, which subsequently leads to excessive superoxide anion radical $\left(\mathrm{O}_{2}^{-}\right)$production in the mitochondria. This compound also produces a breakdown of the mitochondrial membrane potential followed by cytochrome c release as an initial, irreversible step of apoptosis induction. Thus, mitochondria serve as novel cellular targets for naturally occurring anticancer drugs [163]. In addition, apoptosis induction through ROS generation by xanthoangelol (33), a major constituent of Angelica keiskei, was described by Motani et al. in neuroblastoma [121]. Another component of this plant, isobavachalcone (15), induced apoptosis in neuroblastoma by downregulation of 


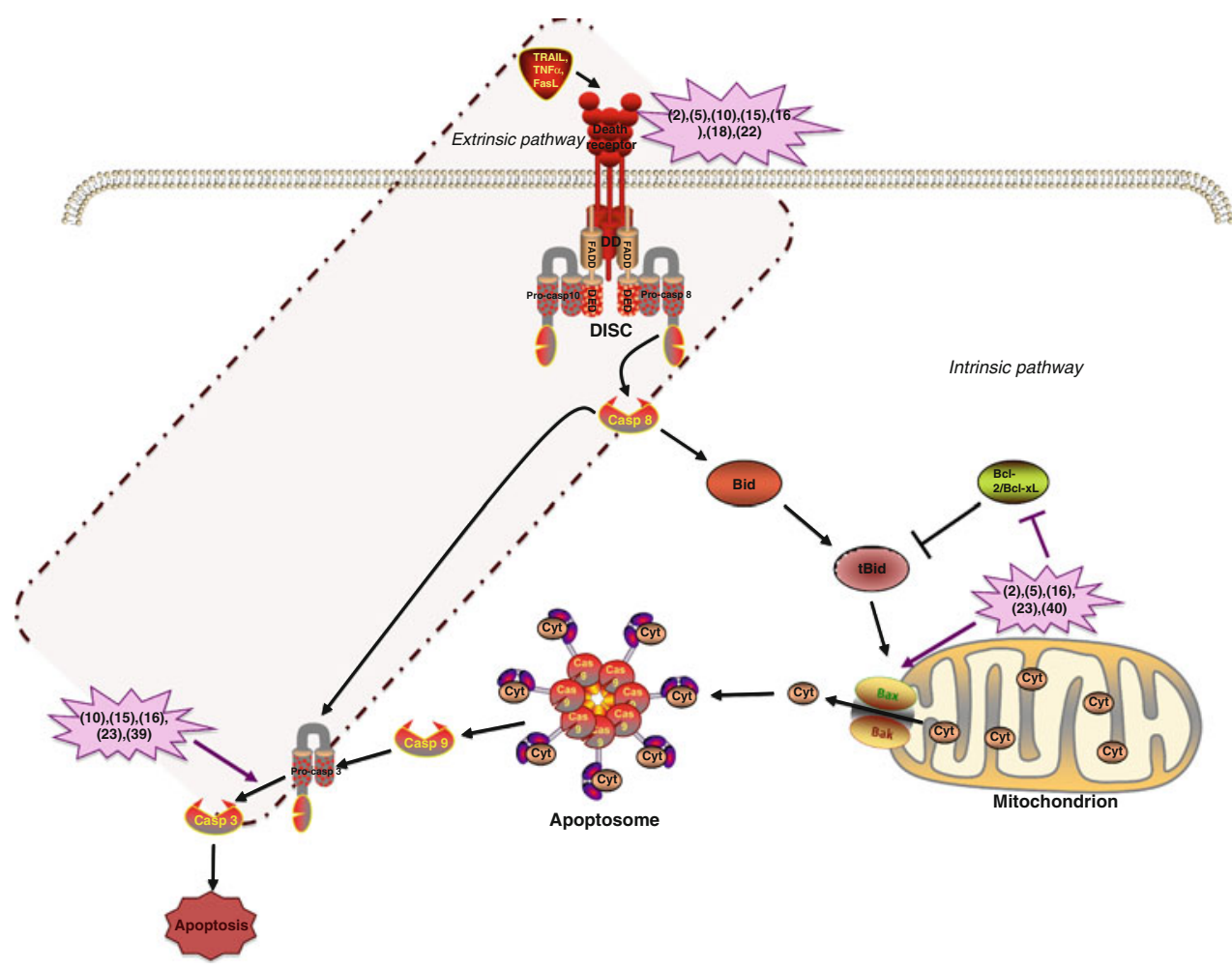

Fig. 6 Involvement of naturally occurring chalcone derivatives in apoptotic cell death. Chalcones potentiate the extrinsic apoptotic pathway: chalcones enhance the apoptosis-inducing potential of TRAIL partially by increased expression of death receptors DR4 and DR5 (chalcones $2, \mathbf{5}, \mathbf{1 0}, \mathbf{1 5}, \mathbf{1 6}, \mathbf{1 8}, \mathbf{2 2}$ ). Chalcones are implicated in the intrinsic apoptotic pathway: chalcones target mitochondria either by disruption of the mitochondrial membrane potential (chalcones $\mathbf{2}$, 5) or by downregulation of anti-apoptotic proteins like Bcl-xL, Bcl-2, and upregulation of Bax and Bak (chalcones 16, 23, 40). Chalcones

pro-caspase 3 and 9 followed by upregulation of cleaved caspase 3 and 9 and Bax induction, similar to the effects of chalcone (10) in human bladder cancer cells [128, 158]. Moreover, no cytotoxicity was observed against nontransformed cells [128]. A similar mechanism was described for isolespeol (39), isolated from the traditional starch crop Artocarpus communis cultivated in tropical and subtropical regions [33], in human liposarcoma SW-872 cells [187, 188].

$\mathrm{Zi}$ et al. showed evidence that flavokavain A (23), traditionally consumed by South Pacific Islanders in kava tea extract, induced apoptosis in bladder cancer cells partially through both the Bax-dependent, mitochondrial pathway, and the downregulation of anti-apoptotic proteins like Bcl$\mathrm{xL}, \mathrm{x}$-linked inhibitor of apoptosis protein (XIAP), and survivin. Flavokavain A (23) activated caspase 9, caspase 3 , and poly (ADP-ribose) polymerase (PARP) cleavage. Furthermore, loss of mitochondrial membrane potential was followed by a release of cytochrome $\mathrm{c}$ that was linked to an increased Bax/Bcl-xL ratio [194]. The related chalcone flavokavain B (40), which is used in food and induce apoptosis via positive modulation of caspase-3 activity (chalcones 10, 15, 16, 23, 39). Arrows represent induction/activation and blunt-ended lines represent repression/inactivation. Abbreviations: $T N F \alpha$ tumor necrosis factor alpha, TRAIL TNF-related apoptosis-inducing ligand, FasL Fas ligand, FADD Fas-associated death domain, $D D$ death domain, $D E D$ death effector domain, $D I S C$ deathinducing silencing complex, Casp caspase, Bid Bcl-2 interacting domain, $C y t$ cytochrome C. This figure was generated with ScienceSlides software

traditional Chinese medicine, exhibits potently caspaseand mitochondria-dependent apoptotic activity accompanied by cytochrome $\mathrm{c}$ release and translocation of Bak to the mitochondria. Induction of GADD153, which regulates the expression of several Bcl-2 family members and enhances ROS production by depletion of glutathione, has also been observed. In connection with this effect, flavokavain B (40) reduced the expression of prosurvival Bcl-2, amplified the expression of proapoptotic Bim, and triggered intracellular ROS generation in human colon cancer cells [82]. Similarly, Tang et al. [168] showed that flavokavain B (40) caused upregulation of Bim and Puma pro-apoptotic proteins and downregulation of XIAP and survivin anti-apoptotic proteins in androgen-negative prostate cancer cells.

Apoptosis is the most frequently observed mechanism of chalcone-mediated cell death, but it is definitely not the only mechanism. In addition to apoptosis, licochalcone A (18) also induced autophagy-related cell death in $\mathrm{LNCaP}$ prostate cancer cells. Suppression of Bcl-2 expression and downregulation of the mammalian target of rapamycin 
(mTOR) pathway led to the formation of autophagic vacuoles and acidic vesicular organelles, the classical characteristics of autophagy [184].

\section{Effect of chalcones on tumor initiation}

The initiation stage of carcinogenesis is closely related to phase I and II carcinogen metabolism and to elevated production of reactive oxygen species (ROS) and reactive nitrogen species (RNS).

Phase I xenobiotic metabolism represents enzymatic activation that allows processing of pro-carcinogens into carcinogens. However, these metabolites are frequently further transformed by phase II detoxifying enzymes that deactivate harmful radicals and electrophiles. Anti-initiation properties are therefore linked to the inhibition of phase I enzymes (cytochrome (CYP) P450, 1A1, 1A2, 1B1) and/or the induction of phase II enzymes $(\mathrm{NAD}(\mathrm{P}) \mathrm{H}$, quinone reductase $(\mathrm{QR})$, gluthatione $S$-transferase (GST)) [44].

Inhibition of this very early step of carcinogenesis is tightly associated with the well-described antioxidant properties of natural compounds. Production of scavenging ROS (superoxide-, hydroxyl radical, hydrogen peroxide, hypochlorous acid) and NO leads to prevention of oxidative damage to DNA, which would otherwise result in oxidative stressinduced genotoxicity. Overproduction of ROS following the induction of oxidative stress contributes significantly to tumor initiation, and a long-term elevation of ROS levels also plays a role in tumor promotion [80]. Similarly, the involvement of RNS cannot be exclusively assigned to either the initiation or the promotion steps of carcinogenesis [133].

It has been shown that chalcones possessing predominantly hydroxyl and prenyl substituents exhibit important antioxidant properties, specifically the induction of quinone reductase activity [45]. Isoliquiritigenin (2) with three hydroxyl groups acts as a monofunctional inducer of phase II enzymes, including GST and QR by triggering the antioxidant response element (ARE) in the promoter region of the QR gene [20, 24]. Cuendet et al. [25] demonstrated the ability of isoliquiritigenin to induce QR activity in colon and GST activity in rat liver tissue. Furthermore, among 9 isolates identified from Glycyrrhiza glabra, isoliquiritigenin (2) is one of the three most potent antioxidant compounds exhibiting peroxynitrite scavenging activity. It has been demonstrated that this compound inhibits nitric oxide (NO) production [20]. Similarly, 1,2dihydroparatocarpin A (3), a prenylated chalcone isolated from extracts of roots or stolons of licorice, mediated effective antioxidant protection against peroxynitrite and nitric oxide [20, 185].

Additionally, isoliquiritin apioside (4), a phytochemical isolated from the 'Rlicca' fraction of Glycyrrhiza glabra, reduced oxidative stress-induced genotoxicity by inhibiting hydrogen peroxide and 4-nitroquinoline-1-oxide (4-NQO) in human peripheral blood lymphocytes [67].

The prenylated chalcone xanthohumol (5), isolated from beer, strongly inhibited CYP1A activity with an $\mathrm{IC}_{50}$ in the $\mathrm{nM}$ range and almost completely inhibited this activity at low $\mu \mathrm{M}$ concentrations $[42,51]$. Furthermore, a low $\mu \mathrm{M}$ concentration was sufficient to double the specific QR activity, which contributes to detoxification by reduction in reactive quinones to less-reactive hydroquinones [42]. Interestingly, xanthohumol (5) also possessed potent hydroxyl- and peroxyl radical scavenging activities that were 8.9- and 2.9-fold higher, respectively, than the reference compound Trolox. In addition, lipopolysaccharide (LPS)-induced inducible nitric oxide synthase (iNOS) expression and the resulting increase in NO production in RAW 264.7 murine macrophages were decreased in a dose-dependent manner by xanthohumol (5) [44].

Another prenylated antioxidative chalcone, broussochalcone A (6) isolated from Broussonetia papyrifera vent, inhibited NO production in LPS-stimulated RAW 264.7 cells in a dose-dependent manner that was independent from a direct effect on iNOS enzyme activity. From a mechanistic point of view, this compound seems to suppress the NF- $\kappa \mathrm{B}$ pathway resulting in a decreased level of iNOS expression. Broussochalcone A (6) also exhibited free-radical scavenging activity, including superoxide- and hydroxyl-radical inhibition, which may contribute to its antilipid peroxidation activity in rat brain homogenates [19].

Several studies indicate that dihydrochalcones exhibit particularly potent antioxidant properties [23, 118, 151].

Phloretin (7) and its glucoside phloridzin (8), two naturally occurring dihydrochalcones isolated from apples, displayed strong scavenging potential against peroxynitrite [151]. Moreover, phloridzin (8) possesses a remarkable antioxidant activity against superoxide radical, hydrogen peroxide, and hypochlorous acid [23].

Mathiesen et al. [118] reported that myrigalone B (9) from the plant Myrica gale is an interesting scavenger of 1,1-diphenyl-2-picrylhydrazyl (DPPH) radical and an inhibitor of lipid peroxidation in isolated hepatocytes treated with tert-butyl hyperoxide.

Interestingly, neohesperidin dihydrochalcone, a hemisynthetic compound used as an intense sweetener and permitted for a commercial use as a food additive in Europe, is produced by the hydrogenation of neohesperidin, which is abundant in citrus fruits. Like phloridzin (8), neohesperidin dihydrochalcone exhibits scavenging activities for various ROS with a preference for non-radical ROS including hydrogen peroxide and hypochlorous acid [23].

Finally, Makita et al. [113] demonstrated that the dietary flavonoids chalcone (10) and 2-hydroxychalcone (11) have an inhibitory effect on 4-NQO-induced oral carcinogenesis. 


\section{Effects of chalcones on tumor promotion}

The second phase of carcinogenesis, tumor promotion, is tightly linked to the initiation phase. Generation and activation of endogenous tumor promoters (prostaglandins (PGs), $17 \beta$-estradiol (E2)) leads to altered gene expression, affects chromatin structure and disturbs signal transduction pathways. Therefore, inhibition of COX-1 and COX-2, which catalyze the formation of PGs, plays an important role in the prevention of tumor promotion [165].

Hormones such as $17 \beta$-estradiol represent another class of endogenous tumor promoters that stimulate cell growth via interaction with estrogen receptors. This interaction leads to increased risk for breast and uterine cancer [150]. Thus, reduction of endogenous estrogen levels is a promising strategy to decrease and prevent tumor promotion [43].

Chronic inflammation also generates elevated levels of NO and contributes to tumor promotion. Xanthohumol (5) has been shown to successfully inhibit iNOS production and both COX-1 and COX -2 activities [42, 43]. The activity of chalcones against inflammatory processes was demonstrated by Zhao et al. [192], who showed potent inhibition of LPS-induced NO production without any cytotoxicity, paralleled by iNOS expression, by xanthohumol (5), xanthohumol B (12), xanthohumol D (13), dihydroxanthohumol (14), and a novel chalcone oxidation product of xanthohumol (5), all isolated from Humulus lupulus. Surprisingly, the suppression of NO production mediated by dihydroxanthohumol, which lacks a double bond between the $\alpha$ and $\beta$ positions, showed much weaker patterns of inhibition than the other 4 chalcones. Altogether, suppression of LPS-induced iNOS protein expression apparently mediates the inhibition of COX-1 and COX-2 by xanthohumol (5) [43]. Furthermore, the antiestrogen potential of xanthohumol (5) was confirmed by efficient inhibition of both human recombinant aromatase and estrogen-mediated induction of alkaline phosphatase (ALP) in Ishikawa human endometrial adenocarcinoma cells. Xanthohumol (5) alone does not possess any intrinsic pro-estrogenic potential [43, 44].

Various chalcone derivatives may positively affect the suppression of tumor promotion initiated by 7,12-dimethylbenz[alpha]anthracene (DMBA) and mediated by 12-Otetradecanoylphorbol-13-acetate (TPA). Isobavachalcone (15), isolated from Angelica keiskei, significantly inhibited in vivo TPA-induced skin tumor promotion in mice [1]. Similar results were obtained with isoliquiritigenin (2), a phenolic constituent of licorice [20]. This compound inhibited TPA-independent tumor promotion in mice treated with DMBA and suppressed TPA-stimulated production of PGE2 in intact epidermal cells. However, it seems that isoliquiritigenin (2) exerts its antitumor-promoting effect through the lipoxygenase (LOX) inhibition in nonepidermal cells because it failed to inhibit 12-LOX and COX in an epidermal subcellular fraction [177]. Ye et al. [182] recently demonstrated that isoliquiritigenin (2) inhibits the CYP19 enzyme (aromatase), which catalyzes rate-limiting step of the conversion of androgens, such as testosterone and androstenedione to estrogens.

Similarly, the plant tetrahydroxychalcone butein (16) is a potent aromatase inhibitor that facilitates downregulation of estrogen synthesis, thereby producing protective effects against the initiation and promotion of breast cancer [173].

Interestingly, a combination of naringenin chalcone (1), the main active component of tomato skin, and 4-hydroxychalcone (17) effectively inhibited aromatase and $17 \beta$-hydroxysteroid dehydrogenase in a low $\mu \mathrm{M}$ range [88].

Licochalcone A (18), another phytochemical isolated from licorice, belongs to a family of promising compounds with potent antitumor activity. In vitro experiments confirmed that licochalcone A suppressed the generation of NO and PGE2 and inhibited the expression of iNOS and COX-2 induced by LPS in RAW 264.7 cells [85].

Within the polyphenol family, prenylated flavonoids are leading molecules for the prevention of tumor promotion due to their unique structure and promising aromatase inhibitory properties. Semisynthetic chalcone analogues of the naturally occurring prenylated flavonoid abyssinone II from Broussonetia papyrifera were tested for their potential to inhibit CYP19. Surprisingly, only one compound showed inhibition potential and it was less potent than racemic abyssinone II. The successful derivative featured two hydroxyl groups on the A ring and one methoxy group accompanied by a 3-methylbutyl-2-enyl substituent on B ring [112].

\section{Effect of chalcones on tumor progression}

Uncontrolled cell proliferation, alterations in terminal cell differentiation, and impairment of apoptosis are key characteristics of tumor cell progression. In this section, we will focus only on the antiproliferative and toxicity-induced effects of natural compounds as the involvement of chalcone derivatives on cell cycle and cell death mechanisms we discussed separately.

Severe side effects, such as nephrotoxicity, hepatotoxicity, ototoxicity, or neurotoxicity, are triggered by currently used chemotherapeutic agents. These adverse impacts on health shift the attention to search for novel drugs among natural compounds with promising bioactivity that lacks such side effects. Thus, combination of naturally occurring compounds with commercially used chemotherapy agents is a promising strategy leading to 
reduction in treatment dosage, reduction in side effects, enhancement of drug efficacy, and reduced drug resistance. Furthermore, identification of compounds with selective cytotoxicity to transformed cells would improve tumor treatment.

Licochalcone A (18) was studied as a candidate for overcoming cisplatin-induced toxicity. Licochalcone A (18) reduced the size of solid tumors and induced neither nephrotoxicity/hepatotoxicity nor oxidative stress. The suppression of proliferation was moderated through reduction in DNA synthesis in CT-26 murine colon carcinoma cells. Oral administration of licochalcone A prior to cisplatin treatment inhibited cisplatin-induced kidney and liver damage as indicated by alterations in the serum NO and tissue lipid peroxidation levels. Licochalcone A (18) was also able to replenish GSH levels [90].

A similar study of isoliquiritigenin (2) confirmed its role in reducing chemotherapy-induced kidney and liver toxicity [89]. It was recently reported that isoliquiritigenin (2) selectively inhibited the proliferation of C4-2 and LNCaP prostate cancer cells, while a similar dosage range did not affect the viability of normal IEC-6 epithelial cells [191]. Isoliquiritigenin (2) has also been shown to significantly reduce viability and proliferation in a dose-dependent manner in uterine leiomyoma cells, human lung cancer cells, and CCRF-CEM leukemia cells. These effects were related to induction of apoptosis and increased cell cycle arrest [59, 68, 195]. Interestingly, isoliquiritigenin (2) downregulates proliferation in HL-60 cells and mediates their monocytic differentiation [100].

Li et al. [102] carried out a detailed phytochemical investigation into Brazilian red Propolis, considered a healthy food in various parts of the world, which led to the isolation of four hydroxychalcone derivatives among more than 40 compounds. Three out of four chalcones possessed a conjugated double bound and showed accentuated cytotoxicity to murine colon 26-L5 carcinoma, murine B16BL6 melanoma, murine Lewis lung carcinoma (LLC), human lung adenocarcinoma A549, human cervix adenocarcinoma HeLa, and human HT-1080 fibrosarcoma cell lines. However, reduction to the single-bond characteristic of hydrochalcones impaired the cytotoxic activity. The authors also stressed the importance of a methoxy substituent at the C-2' position of the A ring and the absence of substituents on the $\mathrm{B}$ ring as a structure that preferentially potentiates cytotoxic properties.

Similar observations were published by De Vincenzo et al. [26] who determined the effects of 15 natural and synthetic chalcones on ovarian cancer cell proliferation. The presence of an $\alpha-\beta$ double bond potentiated the antiproliferative properties of the chalcone scaffold.

Butein (16) and a number of other hydroxy- and dihydroxychalcones were tested for their cytotoxic effect on human colon adenocarcinoma cell proliferation. Butein (16) proved to be the most active compound for growth inhibition [183].

A batch of prenylated flavonoids, including the chalcones xanthohumol (5) and desmethylxanthohumol (26) isolated from Humulus lupulus, has shown in vitro effective inhibition of the proliferation of prostate cancer cells. Xanthohumol (5) appeared to be the most potent compound, whereas the antiproliferative activity of desmethylxanthohumol (26) was weaker [28]. Furthermore, xanthohumol (5) inhibited the activity of human DNA polymerase $\alpha$, the only initiator of de novo DNA synthesis among the eukaryotic polymerases [44].

Likewise, dihydrochalcone asebogenin (27), which is found in several plants, including Piper aduncum, and used as a condiment and for cocoa flavoring, downregulated the proliferation of murine B cells [180].

The primary antiproliferative mechanisms related to growth inhibition in different cancer cell lines are apoptosis induction and blocking of cell cycle progression. These mechanisms have been reported for naturally occurring flavonoids including chalcone (10) (1,3-diphenyl-2-propenon) $[57,158]$, isoliquiritigenin (2) $[55,56]$, and isoliquiritigenin $2^{\prime}$-methyl ether (28) isolated from Caesalpinia sappan [98], butein (16) [120, 137], and 2',4'-dihydroxychalcone (29) from Herba oxytropis [110, 187].

In addition, a huge array of hemisynthetic or synthetic chalcone analogues has been created to identify the most efficient structure for the inhibition of proliferation (see Table 1) $[9,91,95,145,148,156,179]$.

\section{Inhibition of invasion}

Invasion leads to the localized destruction of normal tissue and is linked to the highest mortality in patients with cancer either directly or via metastasis. The first step, local invasiveness, requires escape of the cancer cells from the epithelium of origin (primary tumor) and their migration as separate individuals, known as the epithelial-mesenchymal transition (EMT). The major role in blocking this process is played by the transmembrane glycoprotein E-cadherin. E-cadherin is implicated in cell-cell adhesion by binding epithelial cells together through adherent junctions. Furthermore, E-cadherin forms a complex with catenins, cytoplasmic proteins that link E-cadherin to the actin cytoskeleton. E-cadherin/catenin-mediated intercellular adhesion is essential for the anti-invasive properties of these proteins. Upregulation of the functions of the E-cadherin-catenin invasion-suppressor complex by natural compounds may serve as a target for anti-invasive therapy [143, 172]. Certain plant molecules have been reported to interfere with targets involved in invasion [11, 12, 142].

Plant polyphenolic compounds seem to be promising anti-invasive agents. Xanthohumol (5) and other prenylated 
chalcones exhibit particularly interesting activities [13]. The inhibitory effect of xanthohumol (5) has been shown to be mediated through positive functional regulation of the E-cadherin-catenin invasion-suppressor complex [172].

Parmar et al. [143] screened 100 alkaloid and polyphenolic compounds for their anti-invasive potential. The authors used highly invasive human MCF-7/6 mammary carcinoma cells, which are known for their ability to invade a normal tissue segment within 1 week. These cells were placed in contact with fragments of normal embryonic chick heart. Anti-invasive effects were observed for chalcones presenting a prenyl group. This effect was partially mediated by selective cytotoxicity to MCF-7/6 cells, whereas normal heart tissue was not affected.

Furthermore, a series of studies with prenylated and $O$-allylated chalcones revealed the importance of methoxy groups at the $\mathrm{C}-2$ and $\mathrm{C}-5$ positions and the presence of a bromide atom at the $\mathrm{C}-3$ position of the $\mathrm{B}$ ring of the prenylated derivatives. Among the $O$-allylated chalcones, replacement of the B-phenyl ring with a furan-2-yl group was found to exhibit the strongest anti-invasive properties $[122,144]$.

Isoliquiritigenin (2) has been shown to inhibit basal and epidermal growth factor (EGF)-induced cell migration in a dose-dependent manner. This compound also affects the invasion and adhesion of prostate cancer cells. Interestingly, isoliquiritigenin decreased both basal and EGFinduced activator protein (AP)-1 binding activity and phosphorylation of Jun N-terminal kinase (JNK), c-Jun, and Akt. A subsequent downregulation of protein and mRNA levels of several adhesion molecules (ICAM, VCAM), growth factors (VEGF), and metalloproteinases (MMP)-9 was observed [83].

Because of the loss of cell-cell adhesion mediated by E-cadherin repression and an increase in cell mobility, growing evidence indicates the importance of epithelialmesenchymal transition (EMT) in cancer invasion. Recently, butein (16) has been implicated in the inhibition of cell invasion by bladder cancer cells. The underlying mechanisms include downregulation of the ERK1/2 and NF- $\kappa \mathrm{B}$ signaling pathways associated with reversal of EMT [190]. Furthermore, Pandey et al. [138] described the inhibitory impact of butein on cytokine-induced cellular invasion as a result of the repression of NF- $\kappa \mathrm{B}$-regulated gene products COX-2 and MMP-9.

\section{Inhibition of angiogenesis}

Inhibition of angiogenesis became one of the target strategies of cancer therapy because tumor-induced development of new capillary blood vessels is essential for tumor development, invasion, and metastasis. Angiogenesis and its inhibition are closely linked to endothelial cells, which produce the required factors for microtumor expansion including matrix metalloproteinases (MMPs) and serine proteases. The activity of these proteins allows endothelial cells to initiate capillary sprouting [61]. However, inflammatory cells, which infiltrate the tumor, become an additional target for angiogenetic therapy and the prevention of vascularization. The progressive alteration within the microenvironment including elevated levels of growth factors, chemokines, and proteolytic enzymes contributes greatly to the onset of angiogenesis [3].

Angiogenesis is regulated through multiple signaling pathways (NF- $\kappa \mathrm{B}$, PI3-K/Akt, ERK1/2, hypoxia-inducible factor (HIF)-1 $\alpha$ ), and various mechanisms that lead to modulation of cytokine profiles or alterations in the extracellular microenvironment by MMPs. Some important angiogenic factors are phosphorylation of VEGFR-2 in human umbilical vein endothelial cells (HUVECs) and production of basic or acidic fibroblast growth factors (FGF) and vascular endothelial growth factor (VEGF) in tumors [2].

Many lines of evidence indicate the prominent role of plant polyphenols, including members of the chalcone family, in the fight against pathological angiogenesis (see Table 2) $[6,16,32,34,37,46,49,103-105,116,129-132$, 154, 157, 159, 164]. Hydroxy safflor yellow A (24), a pigment from the flower petals of Carthamus tinctorius, inhibits blood vessel growth of transplanted gastric adenocarcinoma. Xi et al. [176] described downregulation of VEGF and bFGF mRNA expression as the underlying mechanism of inhibition of tumor angiogenesis by this compound.

Isoliquiritin (30), a chalcone isolated from extract of licorice root, was identified as a main compound responsible for an anti-angiogenic effect dependent upon antitube formation [76]. Another licorice-derived flavonoid, isoliquiritigenin (2), negatively affects the aberrant expression of matrix metalloproteinases, which are associated with activated endothelial and tumor cell invasion, through inhibition of the JNK- or p38 MAPK pathways. Furthermore, isoliquiritigenin (2) treatment has been shown to inhibit PMA-induced migration and tube formation [66].

Albini et al. [4] reported that xanthohumol (5) interferes with the molecular mechanisms of cell migration, invasion, and survival and affects several different pathways that result in potent suppression of angiogenesis. Moreover, oral administration of xanthohumol (5) inhibited angiogenesis in a dose-dependent manner in vivo due to the strong reduction in vessel formation, the final morphogenesis phase of angiogenesis. Interestingly, higher doses up to $200 \mu \mathrm{M}$ produced no adverse health effects, suggesting negligible or no toxicity. From a mechanistic point of view, xanthohumol (5) has been shown to inhibit the NF- $\kappa \mathrm{B}$ and Akt pathways. 
Table 2 Plant polyphenols with anti-angiogenic properties

\begin{tabular}{|c|c|c|}
\hline Polyphenolic compound & Molecular target & References \\
\hline Red wine polyphenols & VEGF, pro-MMP-2, (MT1)-MMP & {$[130,132]$} \\
\hline Green tea polyphenols & VEGF, MMP-2, MMP-9 & [116] \\
\hline Epigallocatechin-3-gallate & VEGF & {$[16]$} \\
\hline Delphinidin & VEGF & [131] \\
\hline \multicolumn{3}{|l|}{ Cyanidin } \\
\hline Methylophiopogonanone B & VEGF & [49] \\
\hline Luteolin & VEGF & {$[6]$} \\
\hline Wogonin & VEGF & {$[104,105]$} \\
\hline Genistein & $\begin{array}{l}\text { VEGF, bFGF, uPA, PDGF-A, TF, MMP-2, } \\
\text { MMP-9 }\end{array}$ & $\begin{array}{l}{[34,46,154,} \\
164]\end{array}$ \\
\hline Apigenin & HIF-1, VEGF & {$[32]$} \\
\hline Chrysin & HIF-1, VEGF & {$[37,103]$} \\
\hline Silibinin & MMP-2 & [159] \\
\hline $\begin{array}{l}\text { Flavonoids (acacetin, apigenin, chrysin, genistein, kaempferol, morin, naringin, } \\
\text { naringenin, rutin) }\end{array}$ & VEGF & {$[157]$} \\
\hline
\end{tabular}

Cleistocalyx operculatus, a plant used in traditional Chinese medicine, contains $2^{\prime}, 4^{\prime}$-dihydroxy- $6^{\prime}$-methoxy$3^{\prime}, 5^{\prime}$-dimethylchalcone (ON-III) (31). This compound is known to reversibly inhibit the phosphorylation of VEGFR tyrosine kinase. Additionally, 2', $4^{\prime}$-dihydroxy- $6^{\prime}$-methoxy$3^{\prime}, 5^{\prime}$-dimethylchalcone abrogates VEGFR-mediated signal transduction via suppression of MAPK and Akt activation [78, 126, 135, 152, 174, 193]. Because hydroxylated chalcones are frequent in nature, $2^{\prime}$-hydroxy-4'-methoxychalcone (32) was investigated [99]. Previously, the inhibition of PGE2 production by this chalcone was reported to result from downregulation of COX-2. COX-2 promotes neovascularization through enhanced prostaglandin production and elevated release of angiogenic growth factors [175]. Furthermore, COX-2 has been detected in the angiogenic vasculature of tumors and suppression of angiogenesis by COX inhibitors has been observed [52, 117, 170]. 2'-hydroxy-4'-methoxychalcone (32) was able to suppress vascular formation and inhibit excessive angiogenesis in a bFGF-enhancing matrigel plug assay [99].

Several studies have reported that synthetic or semisynthetic chalcone analogues exhibit anti-angiogenic potential against HUVEC tube formation, development of sprouts during an aortic ring assay, or inhibition of endothelial cell growth in vitro. These compounds include boronic acid chalcone [78], chalcone analogues related to curcumin [174], various chalcone derivatives with a substituted backbone [126, 152], and chalcone carboxylic acid [135].

Inhibition of metastasis

Metastasis, or the ability of cancer cells to infiltrate the normal tissue surrounding a tumor and to travel to another non-adjacent organ and create new tumors, is linked with poor prognosis. The antimetastatic properties of natural compounds are therefore closely related to their anti-angiogenetic and anti-invasive features [73, 190].

Two main components of the roots of Angelica keiskei, xanthoangelol (33) and 4-hydroxyderricin (34), have been identified as potent antimetastatic chalcone derivatives [74, 75]. These compounds inhibited tumor growth and lung metastasis in Lewis lung carcinoma (LLC)-bearing mice, which led to increased survival time of carcinectomized mice. Xanthoangelol (33) also suppressed liver metastasis and the growth of metastasized tumor cells from intrasplenically implanted LLC. The mechanism of these antimetastatic activities has been shown to involve both inhibition of tumor-induced neovascularization and, more significantly, inhibition of DNA synthesis in LLC cells.

Yamazaki et al. showed that isoliquiritigenin (2) induced a significant reduction in metastatic nodules in the lung in a renal mouse cell carcinoma model. Furthermore, this treatment did not cause leukocytopenia, a common feature of a large panel of chemotherapeutic drugs. These results indicate a promising use of isoliquiritigenin (2) as a protective agent against chemotherapy-induced leukocytopenia.

Although the mechanisms of isoliquiritigenin (2) activity were not completely elucidated, the authors suggested that suppression of pulmonary metastasis may result from a combination of isoliquiritigenin-promoted activation of macrophages, lymphocytes, and direct cytotoxicity [178].

Butein (16), the biologically active component of Rhus verniciflua, which is used as a food additive in Korea, showed in vitro disruption of the clonogenic growth of small numbers of primary breast cancer cells seeded into fibroblast co-cultures. These results suggest that butein (16) may suppress the growth of breast cancer micro-metastases [153]. 
As metastasis is a chemokine-guided multistep process based on the dissemination of cancer cells from the primary tumor into specific organs, the control and/or inhibition of specific chemokines provides promising targets. Particular chemokines may promote metastasis by acting directly on tumor cell migration and invasion. CXC chemokine receptor 4 (CXCR4) and its only known ligand, CXC chemokine ligand 12 (CXCL12), are involved in chemotactic regulation of breast cancer metastasis by expressing non-random patterns in all target organs [123, 124].

Müller et al. [123] reported that neutralization of the interaction between CXCL12 and CXCR4 in vivo significantly impairs metastasis of breast cancer cells to regional lymph nodes and to the lung. These results triggered a search for small neutralizing molecules that are able to inhibit CXCL12. Hachet-Haas et al. [47] identified several synthetic chalcone derivatives that reduced binding of CXCL12 to CXCR4. In particular, the structure of 3-chloro-2'-methoxy$3^{\prime}$-hydroxychalcone fits perfectly within the hydrophobic pocket of CXCL12, producing a high-affinity interaction that can disrupt the interaction with CXCR4.

\section{Structure-activity relationship}

Several studies have focused on the discovery of a structure-activity relationship in order to better predict the bioactivity of newly identified chalcone derivatives.

Chalcones that exhibit anti-inflammatory properties generally feature an $\alpha-\beta$ unsaturated bond. This allows the molecule to act as a Michael acceptor for nucleophilic species including glutathione (GSH) or cysteine residues on proteins such as IKK-beta [119]. Generally, these target modifications lead to a major decrease or loss of antiinflammatory activities [62].

Several studies have shown that antiproliferative effects on cancer cells are associated with the presence of one or more hydroxyl substituents on the chalcone scaffold. Hydroxyl derivatives of chalcone have more potent antiproliferation properties than other chalcone derivatives [15, $26,109]$. Furthermore, the presence of $2^{\prime}$-hydroxy group in a chalcone molecule has been shown to be crucial for the enhancement of the anti-inflammatory properties of these molecules. This potent effect was explained by an increase in the electrophilic properties of an $\alpha-\beta$ unsaturated ketone by hydrogen bonding between the $2^{\prime}$-hydroxy group and the ketone moiety (also referred to as the keto, carbonyl, or enone moiety). Moreover, electron-donating groups on the A ring could stabilize the GSH adduct by reducing the acidity of the alpha hydrogen $[63,108]$.

Modification of chalcone structures by substitution with a prenyl side chain also affects their biological activities. Prenylation as protein post-translational modification results in higher protein lipophilicity and targets the modified protein to cell membrane. Therefore, it is assumed that prenylation of chalcone molecules might influence their solubility, cellular uptake, and subcellular localization [44].

Compounds with various glycosidic substitutions on the aromatic rings exhibited attenuated ability to suppress proliferation relative to the corresponding aglycones. A possible explanation is that the reduced lipophilicity caused by the sugar moiety complicates cellular uptake of the compound by passive diffusion through the cell membrane [70, 127].

The ability of chalcone derivatives to interact with the different steps of carcinogenesis has been shown to require specific structural features.

The structural basis for radical scavenging activity seems to be the formation of energetically favored intramolecular hydrogen bonds. Compounds that can adopt conformations in which the A ring and the carbonyl group are orthogonal are more successful radical scavengers [118].

The inhibitory activity of chalcones on NO production is believed to be linked to the presence of an $\alpha-\beta$ double bond. Molecules with a single bond exhibited a weaker effect on NO production than corresponding molecules with an unsaturated bond [192].

Similar mechanisms are valid for the potential of chalcones to inhibit the NF- $\kappa \mathrm{B}$ pathway. The reduction in the alkene into a single bond completely attenuates their inhibition potential [161].

The primary structural feature responsible for microtubule depolymerization activity was hypothesized by comparison with the structure of colchicine. Colchicine inhibits microtubule polymerization by binding to tubulin. The chalcone possessing 3,4,5-trimethoxyphenyl groups on the A ring and an $\alpha$-methyl group within the enone moiety fits better into the colchicine-binding site of tubulin than other chalcone derivatives. Thus, alpha-methyl chalcones are believed to exhibit greater cytotoxic activity than unsubstituted analogues [30].

A study of induction of HO-1 by methoxychalcones revealed that an increasing number of methoxy groups on the aromatic rings at the $3,4,5$ and $3^{\prime}, 4^{\prime}, 5^{\prime}$ positions correlated with progressive induction of $\mathrm{HO}-1$, while methoxy substituents at the $2,4,6$ positions or alone at the 4 and $4^{\prime}$ position were ineffective [155].

\section{Conclusion}

Nature offers a large reservoir of bioactive compounds. The use of these compounds in the treatment of various diseases, including cancer, might complement or even substitute for current medical therapeutic strategies. 
Whereas some molecules apparently act via a single mechanism and thus target one particular cellular process, many chalcones apparently act as multifunctional compounds. Xanthohumol (5) and isoliquiritigenin (2) are representatives of this second category. These chalcones are involved in various steps of carcinogenesis from tumor initiation to metastasis formation and do not appear to be specifically targeted. Despite the fact that their mechanisms seem to be nonspecific, they might nevertheless selectively target one distinct regulatory protein that modulates many downstream signaling pathways and thus initiate a cascade of cellular events that lead to the described spectrum of effects. Obviously, structural requirements play an essential role and are correlated to the observed bioactivity. Therefore, the identification and precise characterization of naturally occurring chalcones, whether as nutraceuticals or as novel therapeutic agents, is a promising approach to fight illnesses such as cancer. Although chalcone derivatives are common in nature, the fast and simple synthesis or chemical modification of chalcones allows rapid generation of large numbers of novel compounds that may be useful for both chemoprevention and inhibition of carcinogenesis.

Acknowledgments BO is supported by a Télévie grant (Fonds National de la Recherche Scientifique, Belgium). Dr. Diederich's research at the Laboratoire de Biologie Moléculaire et Cellulaire du Cancer (LBMCC) is financially supported by the "Recherche Cancer et Sang" foundation, "Recherches Scientifiques Luxembourg", the "Een Häerz fir Kriibskrank Kanner" association, the Action Lions "Vaincre le Cancer" Luxembourg and Televie Luxembourg. Editing and print costs were covered by the Fonds National de la Recherche (FNR), Luxembourg.

\section{References}

1. Akihisa T, Tokuda H, Hasegawa D, Ukiya M, Kimura Y, Enjo F, Suzuki T, Nishino H (2006) Chalcones and other compounds from the exudates of Angelica keiskei and their cancer chemopreventive effects. J Nat Prod 69:38-42

2. Albini A, Noonan DM, Ferrari N (2007) Molecular pathways for cancer angioprevention. Clin Cancer Res 13:4320-4325

3. Albini A, Tosetti F, Benelli R, Noonan DM (2005) Tumor inflammatory angiogenesis and its chemoprevention. Cancer Res 65:10637-10641

4. Albini A, Dell'Eva R, Vene R, Ferrari N, Buhler DR, Noonan DM, Fassina G (2006) Mechanisms of the antiangiogenic activity by the hop flavonoid xanthohumol: NF-kappaB and Akt as targets. FASEB J 20:527-529

5. Alcaraz MJ, Vicente AM, Araico A, Dominguez JN, Terencio MC, Ferrandiz ML (2004) Role of nuclear factor-kappaB and heme oxygenase- 1 in the mechanism of action of an antiinflammatory chalcone derivative in RAW 264.7 cells. Br J Pharmacol 142:1191-1199

6. Bagli E, Stefaniotou M, Morbidelli L, Ziche M, Psillas K, Murphy C, Fotsis T (2004) Luteolin inhibits vascular endothelial growth factor-induced angiogenesis; inhibition of endothelial cell survival and proliferation by targeting phosphatidylinositol 3'-kinase activity. Cancer Res 64:7936-7946
7. Bandgar BP, Gawande SS (2010) Synthesis and biological screening of a combinatorial library of beta-chlorovinyl chalcones as anticancer, anti-inflammatory and antimicrobial agents. Bioorg Med Chem 18:2060-2065

8. Bandgar BP, Gawande SS, Bodade RG, Totre JV, Khobragade CN (2010) Synthesis and biological evaluation of simple methoxylated chalcones as anticancer, anti-inflammatory and antioxidant agents. Bioorg Med Chem 18:1364-1370

9. Boumendjel A, Boccard J, Carrupt PA, Nicolle E, Blanc M, Geze A, Choisnard L, Wouessidjewe D, Matera EL, Dumontet C (2008) Antimitotic and antiproliferative activities of chalcones: forward structure-activity relationship. J Med Chem 51:23072310

10. Boumendjel A, McLeer-Florin A, Champelovier P, Allegro D, Muhammad D, Souard F, Derouazi M, Peyrot V, Toussaint B, Boutonnat J (2009) A novel chalcone derivative which acts as a microtubule depolymerising agent and an inhibitor of P-gp and $\mathrm{BCRP}$ in in vitro and in vivo glioblastoma models. BMC Cancer 9:242

11. Bracke ME, Van Cauwenberge RM, Mareel MM (1984) (+)Catechin inhibits the invasion of malignant fibrosarcoma cells into chick heart in vitro. Clin Exp Metastasis 2:161-170

12. Bracke ME, Vyncke BM, Van Larebeke NA, Bruyneel EA, De Bruyne GK, De Pestel GH, De Coster WJ, Espeel MF, Mareel MM (1989) The flavonoid tangeretin inhibits invasion of MO4 mouse cells into embryonic chick heart in vitro. Clin Exp Metastasis 7:283-300

13. Bracke ME, Vanhoecke BW, Derycke L, Bolca S, Possemiers S, Heyerick A, Stevens CV, De Keukeleire D, Depypere HT, Verstraete W, Williams CA, McKenna ST, Tomar S, Sharma D, Prasad AK, DePass AL, Parmar VS (2008) Plant polyphenolics as anti-invasive cancer agents. Anticancer Agents Med Chem $8: 171-185$

14. Buolamwini JK, Addo J, Kamath S, Patil S, Mason D, Ores M (2005) Small molecule antagonists of the MDM2 oncoprotein as anticancer agents. Curr Cancer Drug Targets 5:57-68

15. Cabrera M, Simoens M, Falchi G, Lavaggi ML, Piro OE, Castellano EE, Vidal A, Azqueta A, Monge A, de Cerain AL, Sagrera G, Seoane G, Cerecetto H, Gonzalez M (2007) Synthetic chalcones, flavanones, and flavones as antitumoral agents: biological evaluation and structure-activity relationships. Bioorg Med Chem 15:3356-3367

16. Cao Y, Cao R (1999) Angiogenesis inhibited by drinking tea. Nature 398:381

17. Chang HJ, Yoon G, Park JS, Kim MH, Baek MK, Kim NH, Shin BA, Ahn BW, Cheon SH, Jung YD (2007) Induction of apoptosis by the licochalcone $\mathrm{E}$ in endothelial cells via modulation of NF-kappaB and Bcl-2 family. Biol Pharm Bull 30:2290-2293

18. Chen TT, Du YJ, Liu XL, Zhu HB (2008) Inhibitory action of hydroxysafflor yellow A on inflammatory signal transduction pathway related factors in rats with cerebral cortex ischemia. Yao Xue Xue Bao 43:570-575

19. Cheng Z, Lin C, Hwang T, Teng C (2001) Broussochalcone A, a potent antioxidant and effective suppressor of inducible nitric oxide synthase in lipopolysaccharide-activated macrophages. Biochem Pharmacol 61:939-946

20. Chin YW, Jung HA, Liu Y, Su BN, Castoro JA, Keller WJ, Pereira MA, Kinghorn AD (2007) Anti-oxidant constituents of the roots and stolons of licorice (Glycyrrhiza glabra). J Agric Food Chem 55:4691-4697

21. Cho YC, Kim HJ, Kim YJ, Lee KY, Choi HJ, Lee IS, Kang BY (2008) Differential anti-inflammatory pathway by xanthohumol in IFN-gamma and LPS-activated macrophages. Int Immunopharmacol 8:567-573

22. Choi BM, Oh GS, Lee JW, Mok JY, Kim DK, Jeong SI, Jang SI (2010) Prenylated chalcone from Sophora flavescens suppresses 
Th2 chemokine expression induced by cytokines via heme oxygenase-1 in human keratinocytes. Arch Pharm Res 33:753760

23. Choi JM, Yoon BS, Lee SK, Hwang JK, Ryang R (2007) Antioxidant properties of neohesperidin dihydrochalcone: inhibition of hypochlorous acid-induced DNA strand breakage, protein degradation, and cell death. Biol Pharm Bull 30:324-330

24. Cuendet M, Oteham CP, Moon RC, Pezzuto JM (2006) Quinone reductase induction as a biomarker for cancer chemoprevention. J Nat Prod 69:460-463

25. Cuendet M, Guo J, Luo Y, Chen S, Oteham CP, Moon RC, van Breemen RB, Marler LE, Pezzuto JM (2010) Cancer chemopreventive activity and metabolism of isoliquiritigenin, a compound found in licorice. Cancer Prev Res (Phila Pa) 3:221-232

26. De Vincenzo R, Scambia G, Benedetti Panici P, Ranelletti FO, Bonanno G, Ercoli A, Delle Monache F, Ferrari F, Piantelli M, Mancuso S (1995) Effect of synthetic and naturally occurring chalcones on ovarian cancer cell growth: structure-activity relationships. Anticancer Drug Des 10:481-490

27. Dean JL, Brook M, Clark AR, Saklatvala J (1999) p38 mitogenactivated protein kinase regulates cyclooxygenase-2 mRNA stability and transcription in lipopolysaccharide-treated human monocytes. J Biol Chem 274:264-269

28. Delmulle L, Bellahcene A, Dhooge W, Comhaire F, Roelens F, Huvaere K, Heyerick A, Castronovo V, De Keukeleire D (2006) Anti-proliferative properties of prenylated flavonoids from hops (Humulus lupulus L.) in human prostate cancer cell lines. Phytomedicine 13:732-734

29. Di Carlo G, Mascolo N, Izzo AA, Capasso F (1999) Flavonoids: old and new aspects of a class of natural therapeutic drugs. Life Sci 65:337-353

30. Ducki S, Forrest R, Hadfield JA, Kendall A, Lawrence NJ, McGown AT, Rennison D (1998) Potent antimitotic and cell growth inhibitory properties of substituted chalcones. Bioorg Med Chem Lett 8:1051-1056

31. Ducki S, Rennison D, Woo M, Kendall A, Chabert JF, McGown AT, Lawrence NJ (2009) Combretastatin-like chalcones as inhibitors of microtubule polymerization. Part 1: synthesis and biological evaluation of antivascular activity. Bioorg Med Chem 17:7698-7710

32. Fang J, Zhou Q, Liu LZ, Xia C, Hu X, Shi X, Jiang BH (2007) Apigenin inhibits tumor angiogenesis through decreasing HIF1 alpha and VEGF expression. Carcinogenesis 28:858-864

33. Fang SC, Hsu CL, Yu YS, Yen GC (2008) Cytotoxic effects of new geranyl chalcone derivatives isolated from the leaves of Artocarpus communis in SW 872 human liposarcoma cells. J Agric Food Chem 56:8859-8868

34. Farina HG, Pomies M, Alonso DF, Gomez DE (2006) Antitumor and antiangiogenic activity of soy isoflavone genistein in mouse models of melanoma and breast cancer. Oncol Rep 16:885-891

35. Ferrer JL, Jez JM, Bowman ME, Dixon RA, Noel JP (1999) Structure of chalcone synthase and the molecular basis of plant polyketide biosynthesis. Nat Struct Biol 6:775-784

36. Folmer F, Blasius R, Morceau F, Tabudravu J, Dicato M, Jaspars M, Diederich M (2006) Inhibition of TNFalpha-induced activation of nuclear factor kappaB by kava (Piper methysticum) derivatives. Biochem Pharmacol 71:1206-1218

37. Fu B, Xue J, Li Z, Shi X, Jiang BH, Fang J (2007) Chrysin inhibits expression of hypoxia-inducible factor-1alpha through reducing hypoxia-inducible factor-1alpha stability and inhibiting its protein synthesis. Mol Cancer Ther 6:220-226

38. Fu Y, Hsieh TC, Guo J, Kunicki J, Lee MY, Darzynkiewicz Z, Wu JM (2004) Licochalcone-A, a novel flavonoid isolated from licorice root (Glycyrrhiza glabra), causes G2 and late-G1 arrests in androgen-independent PC-3 prostate cancer cells. Biochem Biophys Res Commun 322:263-270
39. Funakoshi-Tago M, Tanabe $\mathrm{S}$, Tago $\mathrm{K}$, Itoh $\mathrm{H}$, Mashino $\mathrm{T}$, Sonoda Y, Kasahara T (2009) Licochalcone A potently inhibits tumor necrosis factor alpha-induced nuclear factor-kappaB activation through the direct inhibition of IkappaB kinase complex activation. Mol Pharmacol 76:745-753

40. Furusawa J, Funakoshi-Tago M, Mashino T, Tago K, Inoue H, Sonoda Y, Kasahara T (2009) Glycyrrhiza inflata-derived chalcones, Licochalcone A, Licochalcone B and Licochalcone D, inhibit phosphorylation of NF-kappaB p65 in LPS signaling pathway. Int Immunopharmacol 9:499-507

41. Furusawa J, Funakoshi-Tago M, Tago K, Mashino T, Inoue H, Sonoda Y, Kasahara T (2009) Licochalcone A significantly suppresses LPS signaling pathway through the inhibition of NFkappaB p65 phosphorylation at serine 276. Cell Signal 21:778785

42. Gerhauser C (2002) Isolation and potential cancer chemopreventive activities of phenolic compounds in beer. Phytochem Rev 1:11

43. Gerhauser C (2005) Beer constituents as potential cancer chemopreventive agents. Eur J Cancer 41:1941-1954

44. Gerhauser C, Alt A, Heiss E, Gamal-Eldeen A, Klimo K, Knauft J, Neumann I, Scherf HR, Frank N, Bartsch H, Becker H (2002) Cancer chemopreventive activity of Xanthohumol, a natural product derived from hop. Mol Cancer Ther 1:959-969

45. Go ML, Wu X, Liu XL (2005) Chalcones: an update on cytotoxic and chemoprotective properties. Curr Med Chem 12:481-499

46. Guo Y, Wang S, Hoot DR, Clinton SK (2007) Suppression of VEGF-mediated autocrine and paracrine interactions between prostate cancer cells and vascular endothelial cells by soy isoflavones. J Nutr Biochem 18:408-417

47. Hachet-Haas M, Balabanian K, Rohmer F, Pons F, Franchet C, Lecat S, Chow KY, Dagher R, Gizzi P, Didier B, Lagane B, Kellenberger E, Bonnet D, Baleux F, Haiech J, Parmentier M, Frossard N, Arenzana-Seisdedos F, Hibert M, Galzi JL (2008) Small neutralizing molecules to inhibit actions of the chemokine CXCL12. J Biol Chem 283:23189-23199

48. Harikumar KB, Kunnumakkara AB, Ahn KS, Anand P, Krishnan S, Guha S, Aggarwal BB (2009) Modification of the cysteine residues in IkappaBalpha kinase and NF-kappaB (p65) by xanthohumol leads to suppression of NF-kappaB-regulated gene products and potentiation of apoptosis in leukemia cells. Blood 113:2003-2013

49. Hasebe Y, Egawa K, Yamazaki Y, Kunimoto S, Hirai Y, Ida Y, Nose K (2003) Specific inhibition of hypoxia-inducible factor (HIF)-1 alpha activation and of vascular endothelial growth factor (VEGF) production by flavonoids. Biol Pharm Bull 26:1379-1383

50. Hatziieremia S, Gray AI, Ferro VA, Paul A, Plevin R (2006) The effects of cardamonin on lipopolysaccharide-induced inflammatory protein production and MAP kinase and NFkappaB signalling pathways in monocytes/macrophages. Br J Pharmacol 149:188-198

51. Henderson MC, Miranda CL, Stevens JF, Deinzer ML, Buhler DR (2000) In vitro inhibition of human P450 enzymes by prenylated flavonoids from hops, Humulus lupulus. Xenobiotica 30:235-251

52. Hernandez GL, Volpert OV, Iniguez MA, Lorenzo E, MartinezMartinez S, Grau R, Fresno M, Redondo JM (2001) Selective inhibition of vascular endothelial growth factor-mediated angiogenesis by cyclosporin A: roles of the nuclear factor of activated T cells and cyclooxygenase 2. J Exp Med 193:607-620

53. Hirai S, Kim YI, Goto T, Kang MS, Yoshimura M, Obata A, Yu R, Kawada T (2007) Inhibitory effect of naringenin chalcone on inflammatory changes in the interaction between adipocytes and macrophages. Life Sci 81:1272-1279 
54. Hsu YL, Kuo PL, Lin CC (2005) Isoliquiritigenin induces apoptosis and cell cycle arrest through p53-dependent pathway in Hep G2 cells. Life Sci 77:279-292

55. Hsu YL, Kuo PL, Chiang LC, Lin CC (2004) Isoliquiritigenin inhibits the proliferation and induces the apoptosis of human non-small cell lung cancer a549 cells. Clin Exp Pharmacol Physiol 31:414-418

56. Hsu YL, Kuo PL, Lin LT, Lin CC (2005) Isoliquiritigenin inhibits cell proliferation and induces apoptosis in human hepatoma cells. Planta Med 71:130-134

57. Hsu YL, Kuo PL, Tzeng WS, Lin CC (2006) Chalcone inhibits the proliferation of human breast cancer cell by blocking cell cycle progression and inducing apoptosis. Food Chem Toxicol 44:704-713

58. Hsu YL, Chia CC, Chen PJ, Huang SE, Huang SC, Kuo PL (2009) Shallot and licorice constituent isoliquiritigenin arrests cell cycle progression and induces apoptosis through the induction of ATM/p53 and initiation of the mitochondrial system in human cervical carcinoma HeLa cells. Mol Nutr Food Res 53:826-835

59. Ii T, Satomi Y, Katoh D, Shimada J, Baba M, Okuyama T, Nishino H, Kitamura N (2004) Induction of cell cycle arrest and p21(CIP1/WAF1) expression in human lung cancer cells by isoliquiritigenin. Cancer Lett 207:27-35

60. Israf DA, Khaizurin TA, Syahida A, Lajis NH, Khozirah S (2007) Cardamonin inhibits COX and iNOS expression via inhibition of p65NF-kappaB nuclear translocation and Ikappa-B phosphorylation in RAW 264.7 macrophage cells. Mol Immunol 44:673-679

61. Jekunen A, Kairemo K (2003) Inhibition of angiogenesis at endothelial cell level. Microsc Res Tech 60:85-97

62. Jin F, Jin XY, Jin YL, Sohn DW, Kim SA, Sohn DH, Kim YC, Kim HS (2007) Structural requirements of $2^{\prime}, 4^{\prime}, 6^{\prime}$ tris(methoxymethoxy) chalcone derivatives for anti-inflammatory activity: the importance of a 2'-hydroxy moiety. Arch Pharm Res 30:1359-1367

63. Jin YL, Jin XY, Jin F, Sohn DH, Kim HS (2008) Structure activity relationship studies of anti-inflammatory TMMC derivatives: 4-dimethylamino group on the $\mathrm{B}$ ring responsible for lowering the potency. Arch Pharm Res 31:1145-1152

64. Jung JI, Lim SS, Choi HJ, Cho HJ, Shin HK, Kim EJ, Chung WY, Park KK, Park JH (2006) Isoliquiritigenin induces apoptosis by depolarizing mitochondrial membranes in prostate cancer cells. J Nutr Biochem 17:689-696

65. Kanazawa M, Satomi Y, Mizutani Y, Ukimura O, Kawauchi A, Sakai T, Baba M, Okuyama T, Nishino H, Miki T (2003) Isoliquiritigenin inhibits the growth of prostate cancer. Eur Urol 43:580-586

66. Kang SW, Choi JS, Choi YJ, Bae JY, Li J, Kim DS, Kim JL, Shin SY, Lee YJ, Kwun IS, Kang YH (2010) Licorice isoliquiritigenin dampens angiogenic activity via inhibition of MAPK-responsive signaling pathways leading to induction of matrix metalloproteinases. J Nutr Biochem 21:55-65

67. Kaur P, Kaur S, Kumar N, Singh B, Kumar S (2009) Evaluation of antigenotoxic activity of isoliquiritin apioside from Glycyrrhiza glabra L. Toxicol In Vitro 23:680-686

68. Kim DC, Ramachandran S, Baek SH, Kwon SH, Kwon KY, Cha SD, Bae I, Cho CH (2008) Induction of growth inhibition and apoptosis in human uterine leiomyoma cells by isoliquiritigenin. Reprod Sci 15:552-558

69. Kim do Y, Kim KH, Kim ND, Lee KY, Han CK, Yoon JH, Moon SK, Lee SS, Seong BL (2006) Design and biological evaluation of novel tubulin inhibitors as antimitotic agents using a pharmacophore binding model with tubulin. J Med Chem 49:5664-5670
70. Kim JY, Park SJ, Yun KJ, Cho YW, Park HJ, Lee KT (2008) Isoliquiritigenin isolated from the roots of Glycyrrhiza uralensis inhibits LPS-induced iNOS and COX-2 expression via the attenuation of NF-kappaB in RAW 264.7 macrophages. Eur J Pharmacol 584:175-184

71. Kim N (2008) Butein sensitizes human leukemia cells to apoptosis induced by tumor necrosis factor-related apoptosis inducing ligand (TRAIL). Arch Pharm Res 31:1179-1186

72. Kim NY, Pae HO, Oh GS, Kang TH, Kim YC, Rhew HY, Chung HT (2001) Butein, a plant polyphenol, induces apoptosis concomitant with increased caspase-3 activity, decreased Bcl-2 expression and increased Bax expression in HL-60 cells. Pharmacol Toxicol 88:261-266

73. Kimura Y (2005) New anticancer agents: in vitro and in vivo evaluation of the antitumor and antimetastatic actions of various compounds isolated from medicinal plants. In Vivo 19:37-60

74. Kimura Y, Baba K (2003) Antitumor and antimetastatic activities of Angelica keiskei roots, part 1: isolation of an active substance, xanthoangelol. Int J Cancer 106:429-437

75. Kimura Y, Taniguchi M, Baba K (2004) Antitumor and antimetastatic activities of 4-hydroxyderricin isolated from Angelica keiskei roots. Planta Med 70:211-219

76. Kobayashi S, Miyamoto T, Kimura I, Kimura M (1995) Inhibitory effect of isoliquiritin, a compound in licorice root, on angiogenesis in vivo and tube formation in vitro. Biol Pharm Bull 18:1382-1386

77. Koca U, Berhow MA, Febres VJ, Champ KI, Carrillo-Mendoza O, Moore GA (2009) Decreasing unpalatable flavonoid components in Citrus: the effect of transformation construct. Physiol Plant 137:101-114

78. Kong Y, Wang K, Edler MC, Hamel E, Mooberry SL, Paige MA, Brown ML (2010) A boronic acid chalcone analog of combretastatin A-4 as a potent anti-proliferation agent. Bioorg Med Chem 18:971-977

79. Kong Y, Grembecka J, Edler MC, Hamel E, Mooberry SL, Sabat M, Rieger J, Brown ML (2005) Structure-based discovery of a boronic acid bioisostere of combretastatin A-4. Chem Biol 12:1007-1014

80. Kovacic P, Jacintho JD (2001) Mechanisms of carcinogenesis: focus on oxidative stress and electron transfer. Curr Med Chem 8:773-796

81. Kumar S, Sharma A, Madan B, Singhal V, Ghosh B (2007) Isoliquiritigenin inhibits IkappaB kinase activity and ROS generation to block TNF-alpha induced expression of cell adhesion molecules on human endothelial cells. Biochem Pharmacol 73:1602-1612

82. Kuo Y-F (2010) Flavokawain B, a novel chalcone from Alpinia pricei Hayata with potent apoptotic activity: Involvement of ROS and GADD153 upstream of mitochondria-dependent apoptosis in HCT116 cells. Free Radic Biol Med 49

83. Kwon GT, Cho HJ, Chung WY, Park KK, Moon A, Park JH (2009) Isoliquiritigenin inhibits migration and invasion of prostate cancer cells: possible mediation by decreased JNK/AP1 signaling. J Nutr Biochem 20:663-676

84. Kwon HM, Choi YJ, Choi JS, Kang SW, Bae JY, Kang IJ, Jun JG, Lee SS, Lim SS, Kang YH (2007) Blockade of cytokineinduced endothelial cell adhesion molecule expression by licorice isoliquiritigenin through NF-kappaB signal disruption. Exp Biol Med (Maywood) 232:235-245

85. Kwon HS, Park JH, Kim DH, Kim YH, Shin HK, Kim JK (2008) Licochalcone A isolated from licorice suppresses lipopolysaccharide-stimulated inflammatory reactions in RAW264.7 cells and endotoxin shock in mice. J Mol Med 86:1287-1295

86. Lawrence NJ, McGown AT, Ducki S, Hadfield JA (2000) The interaction of chalcones with tubulin. Anticancer Drug Des 15:135-141 
87. Lawrence NJ, Rennison D, McGown AT, Ducki S, Gul LA, Hadfield JA, Khan N (2001) Linked parallel synthesis and MTT bioassay screening of substituted chalcones. J Comb Chem 3:421-426

88. Le Bail JC, Pouget C, Fagnere C, Basly JP, Chulia AJ, Habrioux G (2001) Chalcones are potent inhibitors of aromatase and 17beta-hydroxysteroid dehydrogenase activities. Life Sci 68: 751-761

89. Lee CK, Son SH, Park KK, Park JH, Lim SS, Chung WY (2008) Isoliquiritigenin inhibits tumor growth and protects the kidney and liver against chemotherapy-induced toxicity in a mouse xenograft model of colon carcinoma. J Pharmacol Sci 106: 444-451

90. Lee CK, Son SH, Park KK, Park JH, Lim SS, Kim SH, Chung WY (2008) Licochalcone A inhibits the growth of colon carcinoma and attenuates cisplatin-induced toxicity without a loss of chemotherapeutic efficacy in mice. Basic Clin Pharmacol Toxicol 103:48-54

91. Lee SA, Ryu HW, Kim YM, Choi S, Lee MJ, Kwak TK, Kim HJ, Cho M, Park KH, Lee JW (2009) Blockade of four-transmembrane L6 family member 5 (TM4SF5)-mediated tumorigenicity in hepatocytes by a synthetic chalcone derivative. Hepatology 49:1316-1325

92. Lee SH, Seo GS, Jin XY, Ko G, Sohn DH (2007) Butein blocks tumor necrosis factor alpha-induced interleukin 8 and matrix metalloproteinase 7 production by inhibiting p38 kinase and osteopontin mediated signaling events in HT-29 cells. Life Sci 81:1535-1543

93. Lee SH, Kim JY, Seo GS, Kim YC, Sohn DH (2009) Isoliquiritigenin, from Dalbergia odorifera, up-regulates antiinflammatory heme oxygenase-1 expression in RAW264.7 macrophages. Inflamm Res 58:257-262

94. Lee SH, Seo GS, Kim JY, Jin XY, Kim HD, Sohn DH (2006) Heme oxygenase 1 mediates anti-inflammatory effects of $2^{\prime}, 4^{\prime}, 6^{\prime}$-tris(methoxymethoxy) chalcone. Eur J Pharmacol 532: $178-186$

95. Lee SH, Seo GS, Kim HS, Woo SW, Ko G, Sohn DH (2006) $2^{\prime}, 4^{\prime}, 6^{\prime}$-Tris(methoxymethoxy) chalcone attenuates hepatic stellate cell proliferation by a heme oxygenase-dependent pathway. Biochem Pharmacol 72:1322-1333

96. Lee SH, Sohn DH, Jin XY, Kim SW, Choi SC, Seo GS (2007) $2^{\prime}, 4^{\prime}, 6^{\prime}$-tris(methoxymethoxy) chalcone protects against trinitrobenzene sulfonic acid-induced colitis and blocks tumor necrosis factor-alpha-induced intestinal epithelial inflammation via heme oxygenase 1-dependent and independent pathways. Biochem Pharmacol 74:870-880

97. Lee YM, Lim do Y, Choi HJ, Jung JI, Chung WY, Park JH (2009) Induction of cell cycle arrest in prostate cancer cells by the dietary compound isoliquiritigenin. J Med Food 12:8-14

98. Lee YM, Jeong GS, Lim HD, An RB, Kim YC, Kim EC (2010) Isoliquiritigenin $2^{\prime}$-methyl ether induces growth inhibition and apoptosis in oral cancer cells via heme oxygenase-1. Toxicol In Vitro 24:776-782

99. Lee YS, Lim SS, Shin KH, Kim YS, Ohuchi K, Jung SH (2006) Anti-angiogenic and anti-tumor activities of $2^{\prime}$-hydroxy-4'methoxychalcone. Biol Pharm Bull 29:1028-1031

100. Li D, Wang Z, Chen H, Wang J, Zheng Q, Shang J, Li J (2009) Isoliquiritigenin induces monocytic differentiation of HL-60 cells. Free Radic Biol Med 46:731-736

101. Li DD, Wu XQ, Tang J, Wei XY, Zhu XF (2009) ON-III inhibits erbB-2 tyrosine kinase receptor signal pathway and triggers apoptosis through induction of Bim in breast cancer cells. Cancer Biol Ther 8:739-743

102. Li F, Awale S, Tezuka Y, Kadota S (2008) Cytotoxic constituents from Brazilian red propolis and their structure-activity relationship. Bioorg Med Chem 16:5434-5440
103. Lin CM, Chang H, Li SY, Wu IH, Chiu JH (2006) Chrysin inhibits lipopolysaccharide-induced angiogenesis via downregulation of VEGF/VEGFR-2(KDR) and IL-6/IL-6R pathways. Planta Med 72:708-714

104. Lin CM, Chang H, Chen YH, Wu IH, Chiu JH (2006) Wogonin inhibits IL-6-induced angiogenesis via down-regulation of VEGF and VEGFR-1, not VEGFR-2. Planta Med 72:1305-1310

105. Lin CM, Chang H, Chen YH, Li SY, Wu IH, Chiu JH (2006) Protective role of wogonin against lipopolysaccharide-induced angiogenesis via VEGFR-2, not VEGFR-1. Int Immunopharmacol 6:1690-1698

106. Liu X, Go ML (2006) Antiproliferative properties of piperidinylchalcones. Bioorg Med Chem 14:153-163

107. Liu X, Go ML (2007) Antiproliferative activity of chalcones with basic functionalities. Bioorg Med Chem 15:7021-7034

108. Liu YC, Hsieh CW, Wu CC, Wung BS (2007) Chalcone inhibits the activation of NF-kappaB and STAT3 in endothelial cells via endogenous electrophile. Life Sci 80:1420-1430

109. Loa J, Chow P, Zhang K (2009) Studies of structure-activity relationship on plant polyphenol-induced suppression of human liver cancer cells. Cancer Chemother Pharmacol 63:1007-1016

110. Lou C, Wang M, Yang G, Cai H, Li Y, Zhao F, Yang H, Tong L, Cai B (2009) Preliminary studies on anti-tumor activity of $2^{\prime}, 4^{\prime}$ dihydroxychalcone isolated from Herba Oxytropis in human gastric cancer MGC-803 cells. Toxicol In Vitro 23:906-910

111. Ma J, Fu NY, Pang DB, Wu WY, Xu AL (2001) Apoptosis induced by isoliquiritigenin in human gastric cancer MGC-803 cells. Planta Med 67:754-757

112. Maiti A, Cuendet M, Croy VL, Endringer DC, Pezzuto JM, Cushman M (2007) Synthesis and biological evaluation of ( \pm )abyssinone II and its analogues as aromatase inhibitors for chemoprevention of breast cancer. J Med Chem 50:2799-2806

113. Makita H, Tanaka T, Fujitsuka H, Tatematsu N, Satoh K, Hara A, Mori H (1996) Chemoprevention of 4-nitroquinoline 1-oxideinduced rat oral carcinogenesis by the dietary flavonoids chalcone, 2-hydroxychalcone, and quercetin. Cancer Res 56:4904-4909

114. Manach C, Scalbert A, Morand C, Remesy C, Jimenez L (2004) Polyphenols: food sources and bioavailability. Am J Clin Nutr 79:727-747

115. Manning AM, Davis RJ (2003) Targeting JNK for therapeutic benefit: from junk to gold? Nat Rev Drug Discov 2:554-565

116. Mantena SK, Meeran SM, Elmets CA, Katiyar SK (2005) Orally administered green tea polyphenols prevent ultraviolet radiationinduced skin cancer in mice through activation of cytotoxic T cells and inhibition of angiogenesis in tumors. J Nutr 135:2871-2877

117. Masferrer JL, Leahy KM, Koki AT, Zweifel BS, Settle SL, Woerner BM, Edwards DA, Flickinger AG, Moore RJ, Seibert K (2000) Antiangiogenic and antitumor activities of cyclooxygenase-2 inhibitors. Cancer Res 60:1306-1311

118. Mathiesen L, Malterud KE, Sund RB (1997) Hydrogen bond formation as basis for radical scavenging activity: a structureactivity study of C-methylated dihydrochalcones from Myrica gale and structurally related acetophenones. Free Radic Biol Med 22:307-311

119. Meng CQ, Ni L, Worsencroft KJ, Ye Z, Weingarten MD, Simpson JE, Skudlarek JW, Marino EM, Suen KL, Kunsch C, Souder A, Howard RB, Sundell CL, Wasserman MA, Sikorski JA (2007) Carboxylated, heteroaryl-substituted chalcones as inhibitors of vascular cell adhesion molecule-1 expression for use in chronic inflammatory diseases. J Med Chem 50:1304-1315

120. Moon DO, Kim MO, Choi YH, Hyun JW, Chang WY, Kim GY (2010) Butein induces $\mathrm{G}(2) / \mathrm{M}$ phase arrest and apoptosis in human hepatoma cancer cells through ROS generation. Cancer Lett 288:204-213

121. Motani K, Tabata K, Kimura Y, Okano S, Shibata Y, Abiko Y, Nagai H, Akihisa T, Suzuki T (2008) Proteomic analysis of 
apoptosis induced by xanthoangelol, a major constituent of Angelica keiskei, in neuroblastoma. Biol Pharm Bull 31:618626

122. Mukherjee S, Kumar V, Prasad AK, Raj HG, Bracke ME, Olsen CE, Jain SC, Parmar VS (2001) Synthetic and biological activity evaluation studies on novel 1, 3-diarylpropenones. Bioorg Med Chem 9:337-345

123. Muller A, Homey B, Soto H, Ge N, Catron D, Buchanan ME, McClanahan T, Murphy E, Yuan W, Wagner SN, Barrera JL, Mohar A, Verastegui E, Zlotnik A (2001) Involvement of chemokine receptors in breast cancer metastasis. Nature 410:50-56

124. Murphy PM (2001) Chemokines and the molecular basis of cancer metastasis. N Engl J Med 345:833-835

125. Nakatani N, Ichimaru M, Moriyasu M, Kato A (2005) Induction of apoptosis in human promyelocytic leukemia cell line HL-60 by C-benzylated dihydrochalcones, uvaretin, isouvaretin and diuvaretin. Biol Pharm Bull 28:83-86

126. Nam NH, Kim Y, You YJ, Hong DH, Kim HM, Ahn BZ (2003) Cytotoxic $2^{\prime}, 5^{\prime}$-dihydroxychalcones with unexpected antiangiogenic activity. Eur J Med Chem 38:179-187

127. Namgoong SY, Son KH, Chang HW, Kang SS, Kim HP (1994) Effects of naturally occurring flavonoids on mitogen-induced lymphocyte proliferation and mixed lymphocyte culture. Life Sci 54:313-320

128. Nishimura R, Tabata K, Arakawa M, Ito Y, Kimura Y, Akihisa T, Nagai H, Sakuma A, Kohno H, Suzuki T (2007) Isobavachalcone, a chalcone constituent of Angelica keiskei, induces apoptosis in neuroblastoma. Biol Pharm Bull 30:1878-1883

129. Oak MH, El Bedoui J, Schini-Kerth VB (2005) Antiangiogenic properties of natural polyphenols from red wine and green tea. J Nutr Biochem 16:1-8

130. Oak MH, El Bedoui J, Anglard P, Schini-Kerth VB (2004) Red wine polyphenolic compounds strongly inhibit pro-matrix metalloproteinase- 2 expression and its activation in response to thrombin via direct inhibition of membrane type 1-matrix metalloproteinase in vascular smooth muscle cells. Circulation 110:1861-1867

131. Oak MH, Bedoui JE, Madeira SV, Chalupsky K, Schini-Kerth VB (2006) Delphinidin and cyanidin inhibit PDGF(AB)-induced VEGF release in vascular smooth muscle cells by preventing activation of p38 MAPK and JNK. Br J Pharmacol 149:283-290

132. Oak MH, Chataigneau M, Keravis T, Chataigneau T, Beretz A, Andriantsitohaina R, Stoclet JC, Chang SJ, Schini-Kerth VB (2003) Red wine polyphenolic compounds inhibit vascular endothelial growth factor expression in vascular smooth muscle cells by preventing the activation of the $\mathrm{p} 38$ mitogen-activated protein kinase pathway. Arterioscler Thromb Vasc Biol 23:10011007

133. Ohshima H, Bartsch H (1994) Chronic infections and inflammatory processes as cancer risk factors: possible role of nitric oxide in carcinogenesis. Mutat Res 305:253-264

134. Ohtsuki T, Kikuchi H, Koyano T, Kowithayakorn T, Sakai T, Ishibashi M (2009) Death receptor 5 promoter-enhancing compounds isolated from Catimbium speciosum and their enhancement effect on TRAIL-induced apoptosis. Bioorg Med Chem 17:6748-6754

135. Oikawa T, Hirotani K, Nakamura O, Shudo K, Hiragun A, Iwaguchi T (1989) A highly potent antiangiogenic activity of retinoids. Cancer Lett 48:157-162

136. Pages G, Guerin S, Grall D, Bonino F, Smith A, Anjuere F, Auberger P, Pouyssegur J (1999) Defective thymocyte maturation in p44 MAP kinase (Erk 1) knockout mice. Science 286:1374-1377

137. Pandey MK, Sung B, Ahn KS, Aggarwal BB (2009) Butein suppresses constitutive and inducible signal transducer and activator of transcription (STAT) 3 activation and STAT3- regulated gene products through the induction of a protein tyrosine phosphatase SHP-1. Mol Pharmacol 75:525-533

138. Pandey MK, Sandur SK, Sung B, Sethi G, Kunnumakkara AB, Aggarwal BB (2007) Butein, a tetrahydroxychalcone, inhibits nuclear factor (NF)-kappaB and NF-kappaB-regulated gene expression through direct inhibition of IkappaBalpha kinase beta on cysteine 179 residue. J Biol Chem 282:17340-17350

139. Park I, Park KK, Park JH, Chung WY (2009) Isoliquiritigenin induces G2 and M phase arrest by inducing DNA damage and by inhibiting the metaphase/anaphase transition. Cancer Lett 277:174-181

140. Park PH, Kim HS, Hur J, Jin XY, Jin YL, Sohn DH (2009) YL-I-108, a synthetic chalcone derivative, inhibits lipopolysaccharide-stimulated nitric oxide production in RAW 264.7 murine macrophages: involvement of heme oxygenase-1 induction and blockade of activator protein-1. Arch Pharm Res 32:79-89

141. Park PH, Kim HS, Jin XY, Jin F, Hur J, Ko G, Sohn DH (2009) KB-34, a newly synthesized chalcone derivative, inhibits lipopolysaccharide-stimulated nitric oxide production in RAW 264.7 macrophages via heme oxygenase-1 induction and blockade of activator protein-1. Eur J Pharmacol 606:215-224

142. Parmar VS, Jain R, Sharma SK, Vardhan A, Jha A, Taneja P, Singh S, Vyncke BM, Bracke ME, Mareel MM (1994) Antiinvasive activity of 3, 7-dimethoxyflavone in vitro. J Pharm Sci 83:1217-1221

143. Parmar VS, Bracke ME, Philippe J, Wengel J, Jain SC, Olsen CE, Bisht KS, Sharma NK, Courtens A, Sharma SK, Vennekens K, Van Marck V, Singh SK, Kumar N, Kumar A, Malhotra S, Kumar R, Rajwanshi VK, Jain R, Mareel MM (1997) Antiinvasive activity of alkaloids and polyphenolics in vitro. Bioorg Med Chem 5:1609-1619

144. Parmar VS, Sharma NK, Husain M, Watterson AC, Kumar J, Samuelson LA, Cholli AL, Prasad AK, Kumar A, Malhotra S, Kumar N, Jha A, Singh A, Singh I, Himanshu Vats A, Shakil NA, Trikha S, Mukherjee S, Sharma SK, Singh SK, Jha HN, Olsen CE, Stove CP, Bracke ME, Mareel MM (2003) Synthesis, characterization and in vitro anti-invasive activity screening of polyphenolic and heterocyclic compounds. Bioorg Med Chem 11:913-929

145. Quintin J, Desrivot J, Thoret S, Le Menez P, Cresteil T, Lewin G (2009) Synthesis and biological evaluation of a series of tangeretin-derived chalcones. Bioorg Med Chem Lett 19:167-169

146. Ralph SJ, Neuzil J (2009) Mitochondria as targets for cancer therapy. Mol Nutr Food Res 53:9-28

147. Rao YK, Fang SH, Tzeng YM (2004) Differential effects of synthesized 2'-oxygenated chalcone derivatives: modulation of human cell cycle phase distribution. Bioorg Med Chem 12:2679-2686

148. Rao YK, Fang SH, Tzeng YM (2009) Synthesis and biological evaluation of $3^{\prime}, 4^{\prime}, 5^{\prime}$-trimethoxychalcone analogues as inhibitors of nitric oxide production and tumor cell proliferation. Bioorg Med Chem 17:7909-7914

149. Rasheed Z, Akhtar N, Khan A, Khan KA, Haqqi TM (2010) Butrin, isobutrin, and butein from medicinal plant Butea monosperma selectively inhibit nuclear factor-kappaB in activated human mast cells: suppression of tumor necrosis factoralpha, interleukin (IL)-6, and IL-8. J Pharmacol Exp Ther 333:354-363

150. Reid SE, Murthy MS, Kaufman M, Scanlon EF (1996) Endocrine and paracrine hormones in the promotion, progression and recurrence of breast cancer. Br J Surg 83:1037-1046

151. Rezk BM, Haenen GR, van der Vijgh WJ, Bast A (2002) The antioxidant activity of phloretin: the disclosure of a new antioxidant pharmacophore in flavonoids. Biochem Biophys Res Commun 295:9-13 
152. Robinson TP, RBt Hubbard, Ehlers TJ, Arbiser JL, Goldsmith DJ, Bowen JP (2005) Synthesis and biological evaluation of aromatic enones related to curcumin. Bioorg Med Chem 13: 4007-4013

153. Samoszuk M, Tan J, Chorn G (2005) The chalcone butein from Rhus verniciflua Stokes inhibits clonogenic growth of human breast cancer cells co-cultured with fibroblasts. BMC Complement Altern Med 5:5

154. Sasamura H, Takahashi A, Yuan J, Kitamura H, Masumori N, Miyao N, Itoh N, Tsukamoto T (2004) Antiproliferative and antiangiogenic activities of genistein in human renal cell carcinoma. Urology 64:389-393

155. Sawle P, Moulton BE, Jarzykowska M, Green CJ, Foresti R, Fairlamb IJ, Motterlini R (2008) Structure-activity relationships of methoxychalcones as inducers of heme oxygenase-1. Chem Res Toxicol 21:1484-1494

156. Saydam G, Aydin HH, Sahin F, Kucukoglu O, Erciyas E, Terzioglu E, Buyukkececi F, Omay SB (2003) Cytotoxic and inhibitory effects of $4,4^{\prime}$-dihydroxy chalcone (RVC-588) on proliferation of human leukemic HL-60 cells. Leuk Res 27: $57-64$

157. Schindler R, Mentlein R (2006) Flavonoids and vitamin E reduce the release of the angiogenic peptide vascular endothelial growth factor from human tumor cells. J Nutr 136:1477-1482

158. Shen KH, Chang JK, Hsu YL, Kuo PL (2007) Chalcone arrests cell cycle progression and induces apoptosis through induction of mitochondrial pathway and inhibition of nuclear factor kappa B signalling in human bladder cancer cells. Basic Clin Pharmacol Toxicol 101:254-261

159. Singh RP, Dhanalakshmi S, Agarwal C, Agarwal R (2005) Silibinin strongly inhibits growth and survival of human endothelial cells via cell cycle arrest and downregulation of survivin, Akt and NF-kappaB: implications for angioprevention and antiangiogenic therapy. Oncogene 24:1188-1202

160. Sporn MB, Liby KT (2005) Cancer chemoprevention: scientific promise, clinical uncertainty. Nat Clin Pract Oncol 2:518-525

161. Srinivasan B, Johnson TE, Lad R, Xing C (2009) Structureactivity relationship studies of chalcone leading to 3-hydroxy$4,3^{\prime}, 4^{\prime}, 5^{\prime}$-tetramethoxychalcone and its analogues as potent nuclear factor kappaB inhibitors and their anticancer activities. J Med Chem 52:7228-7235

162. Stoll R, Renner C, Hansen S, Palme S, Klein C, Belling A, Zeslawski W, Kamionka M, Rehm T, Muhlhahn P, Schumacher R, Hesse F, Kaluza B, Voelter W, Engh RA, Holak TA (2001) Chalcone derivatives antagonize interactions between the human oncoprotein MDM2 and p53. Biochemistry 40:336-344

163. Strathmann J (2010) Xanthohumol-induced transient superoxide anion radical formation triggers cancer cells into apoptosis via a mitochondria-mediated mechanism. FASEB J 24

164. Su SJ, Yeh TM, Chuang WJ, Ho CL, Chang KL, Cheng HL, Liu HS, Hsu PY, Chow NH (2005) The novel targets for antiangiogenesis of genistein on human cancer cells. Biochem Pharmacol 69:307-318

165. Subbaramaiah K, Zakim D, Weksler BB, Dannenberg AJ (1997) Inhibition of cyclooxygenase: a novel approach to cancer prevention. Proc Soc Exp Biol Med 216:201-210

166. Szliszka E, Czuba ZP, Mazur B, Sedek L, Paradysz A, Krol W (2009) Chalcones enhance TRAIL-induced apoptosis in prostate cancer cells. Int J Mol Sci 11:1-13

167. Tang Y, Simoneau AR, Xie J, Shahandeh B, Zi X (2008) Effects of the kava chalcone flavokawain A differ in bladder cancer cells with wild-type versus mutant p53. Cancer Prev Res (Phila Pa) 1:439-451

168. Tang Y, Li X, Liu Z, Simoneau AR, Xie J, Zi X (2010) Flavokawain $\mathrm{B}$, a kava chalcone, induces apoptosis via up-regulation of death-receptor 5 and Bim expression in androgen receptor negative, hormonal refractory prostate cancer cell lines and reduces tumor growth. Int $\mathrm{J}$ Cancer

169. Thorburn A, Behbakht K, Ford H (2008) TRAIL receptor-targeted therapeutics: resistance mechanisms and strategies to avoid them. Drug Resist Updat 11:17-24

170. Tsuji S, Tsujii M, Kawano S, Hori M (2001) Cyclooxygenase-2 upregulation as a perigenetic change in carcinogenesis. J Exp Clin Cancer Res 20:117-129

171. Ullah MF, Khan MW (2008) Food as medicine: potential therapeutic tendencies of plant derived polyphenolic compounds. Asian Pac J Cancer Prev 9:187-195

172. Vanhoecke B, Derycke L, Van Marck V, Depypere H, De Keukeleire D, Bracke M (2005) Antiinvasive effect of xanthohumol, a prenylated chalcone present in hops (Humulus lupulus L.) and beer. Int J Cancer 117:889-895

173. Wang Y, Chan FL, Chen S, Leung LK (2005) The plant polyphenol butein inhibits testosterone-induced proliferation in breast cancer cells expressing aromatase. Life Sci 77:39-51

174. Weber WM, Hunsaker LA, Abcouwer SF, Deck LM, Vander Jagt DL (2005) Anti-oxidant activities of curcumin and related enones. Bioorg Med Chem 13:3811-3820

175. Williams CS, Smalley W, DuBois RN (1997) Aspirin use and potential mechanisms for colorectal cancer prevention. J Clin Invest 100:1325-1329

176. Xi S, Zhang Q, Xie H, Liu L, Liu C, Gao X, Zhang J, Wu L, Qian L, Deng X (2009) Effects of hydroxy safflor yellow A on blood vessel and mRNA expression with VEGF and bFGF of transplantation tumor with gastric adenocarcinoma cell line BGC-823 in nude mice. Zhongguo Zhong Yao Za Zhi 34:605610

177. Yamamoto S, Aizu E, Jiang H, Nakadate T, Kiyoto I, Wang JC, Kato R (1991) The potent anti-tumor-promoting agent isoliquiritigenin. Carcinogenesis 12:317-323

178. Yamazaki S, Morita T, Endo H, Hamamoto T, Baba M, Joichi Y, Kaneko S, Okada Y, Okuyama T, Nishino H, Tokue A (2002) Isoliquiritigenin suppresses pulmonary metastasis of mouse renal cell carcinoma. Cancer Lett 183:23-30

179. Yang X, Wang W, Tan J, Song D, Li M, Liu D, Jing Y, Zhao L (2009) Synthesis of a series of novel dihydroartemisinin derivatives containing a substituted chalcone with greater cytotoxic effects in leukemia cells. Bioorg Med Chem Lett 19:4385-4388

180. Yao GM, Ding Y, Zuo JP, Wang HB, Wang YB, Ding BY, Chiu P, Qin GW (2005) Dihydrochalcones from the leaves of Pieris japonica. J Nat Prod 68:392-396

181. Ye CL, Qian F, Wei DZ, Lu YH, Liu JW (2005) Induction of apoptosis in K562 human leukemia cells by $2^{\prime}, 4^{\prime}$-dihydroxy- $6^{\prime}$ methoxy-3', $5^{\prime}$-dimethylchalcone. Leuk Res 29:887-892

182. Ye L, Gho WM, Chan FL, Chen S, Leung LK (2009) Dietary administration of the licorice flavonoid isoliquiritigenin deters the growth of MCF-7 cells overexpressing aromatase. Int J Cancer 124:1028-1036

183. Yit CC, Das NP (1994) Cytotoxic effect of butein on human colon adenocarcinoma cell proliferation. Cancer Lett 82:65-72

184. Yo YT, Shieh GS, Hsu KF, Wu CL, Shiau AL (2009) Licorice and licochalcone-A induce autophagy in $\mathrm{LNCaP}$ prostate cancer cells by suppression of Bcl-2 expression and the mTOR pathway. J Agric Food Chem 57:8266-8273

185. Yokozawa T, Cho EJ, Rhyu DY, Shibahara N, Aoyagi K (2005) Glycyrrhizae Radix attenuates peroxynitrite-induced renal oxidative damage through inhibition of protein nitration. Free Radic Res 39:203-211

186. Yoshida T, Horinaka M, Takara M, Tsuchihashi M, Mukai N, Wakada M, Sakai T (2008) Combination of isoliquiritigenin and tumor necrosis factor-related apoptosis-inducing ligand induces apoptosis in colon cancer HT29 cells. Environ Health Prev Med $13: 281-287$ 
187. Yun JM, Kwon H, Mukhtar H, Hwang JK (2005) Induction of apoptosis by Panduratin A isolated from Kaempferia pandurata in human colon cancer HT-29 cells. Planta Med 71:501-507

188. Yun JM, Kweon MH, Kwon H, Hwang JK, Mukhtar H (2006) Induction of apoptosis and cell cycle arrest by a chalcone panduratin A isolated from Kaempferia pandurata in androgenindependent human prostate cancer cells PC3 and DU145. Carcinogenesis 27:1454-1464

189. Zhang L, Fang B (2005) Mechanisms of resistance to TRAILinduced apoptosis in cancer. Cancer Gene Ther 12:228-237

190. Zhang L, Chen W, Li X (2008) A novel anticancer effect of butein: inhibition of invasion through the ERK1/2 and NF-kappa B signaling pathways in bladder cancer cells. FEBS Lett 582:1821-1828

191. Zhang X, Yeung ED, Wang J, Panzhinskiy EE, Tong C, Li W, Li J (2010) Natural antioxidant-isoliquiritigenin selectively inhibits proliferation of prostate cancer cells. Clin Exp Pharmacol Physiol
192. Zhao F, Nozawa H, Daikonnya A, Kondo K, Kitanaka S (2003) Inhibitors of nitric oxide production from hops (Humulus lupulus L.). Biol Pharm Bull 26:61-65

193. Zhu XF, Xie BF, Zhou JM, Feng GK, Liu ZC, Wei XY, Zhang FX, Liu MF, Zeng YX (2005) Blockade of vascular endothelial growth factor receptor signal pathway and antitumor activity of ON-III ( $2^{\prime}, 4^{\prime}$-dihydroxy-6'-methoxy-3',5'-dimethylchalcone), a component from Chinese herbal medicine. Mol Pharmacol 67:1444-1450

194. Zi X, Simoneau AR (2005) Flavokawain A, a novel chalcone from kava extract, induces apoptosis in bladder cancer cells by involvement of Bax protein-dependent and mitochondriadependent apoptotic pathway and suppresses tumor growth in mice. Cancer Res 65:3479-3486

195. Zu Y, Liu X, Fu Y, Shi X, Wu N, Yao L, Efferth T (2009) Cytotoxic activity of isoliquiritigenin towards CCRF-CEM leukemia cells and its effect on DNA damage. Planta Med 75:1134-1140 